\title{
Financial Technology: Review of Trends, Approaches and Management
}

\author{
Emilio Abad-Segura ${ }^{1, * \mathbb{C}}$, Mariana-Daniela González-Zamar ${ }^{2, *} \mathbb{C}$, Eloy López-Meneses ${ }^{3,4} \mathbb{C}$ and \\ Esteban Vázquez-Cano 5 (D) \\ 1 Department of Economics and Business, University of Almeria, 04120 Almeria, Spain \\ 2 Department of Education, University of Almeria, 04120 Almeria, Spain \\ 3 Department of Education and Social Psychology, Pablo de Olavide University, 41013 Sevilla, Spain; \\ elopmen@upo.es \\ 4 Research Institute in Social Sciences and Education, Vice-Rectory for Research and Postgraduate, \\ University of Atacama, Copiapó 1530000, Chile \\ 5 Department of Didactics and School Organization, National University of Distance Education, \\ 28040 Madrid, Spain; evazquez@edu.uned.es \\ * Correspondence: eas297@ual.es; (E.A.-S.); mgz857@ual.es (M.-D.G.-Z.)
}

Received: 19 May 2020; Accepted: 9 June 2020; Published: 10 June 2020

\begin{abstract}
Technological innovation and digitization have posed a challenge to the financial sector globally. Fintech is the term used to designate the application of new technologies to financial services. The aim of the study is to analyse this research subject worldwide during the period 1975-2019. To this end, bibliometric techniques were applied to 2012 articles, obtaining findings of the productivity of scientific research, of the main thematic axes and their evolution. Scientific activity increased, mainly in the past decade, with $45 \%$ of publications. The main thematic areas were Business, Management and Accounting, Engineering, Social Sciences and Computer Science. Seven research lines were identified, aimed at analysing the aspects financial, economic, technology transfer, investment, innovation, partnerships and institutions and commercial. Future research lines should develop analyses on banking, financial services trade, territorial development, legal, management, research methodologies and the sustainability of financial technologies. It was verified that there is a growing and dynamic interest in scientific activity on financial technologies at an international level. The findings obtained are a complement to the knowledge of financial technologies and allow the relationship between science and technology to be established, and to inform the decision-making process.
\end{abstract}

Keywords: financial technology; management; finance; innovation; fintech; scientific production

\section{Introduction}

Technological advances and digital transformation imply a paradigm shift in the financial sector. The basis of this revolution is innovation in business models based on emerging technologies at the customer's service [1,2]. Furthermore, the value proposition of financial technologies is based on creativity and the ability to focus on the client with more flexible financial services than those offered by the traditional model. The initial competitiveness between banking and financial technology has evolved into collaboration $[3,4]$.

The development of financial technology proposes: (i) Multichannel assistance for users: smartphones, tablets, PCs, laptops, or smartwatches; (ii) cloud technology, which allows decentralised storage and facilitates financial information and services without the need for physical space; (iii) the use of cryptocurrency, which offers global transactions, fewer intermediaries, or transparency in payments; and (iv) mobile payment, which offers security, speed, and is a new way of doing business and managing money [5-7]. 
The digitisation and connection of devices have allowed the expansion of the global financial system with an increase in banking websites and companies dedicated to digital payments, online loans and crowdfunding, online brokers and electronic transfers. From this perspective, the connection of the terms finance and technology has meant the Fintech term to refer to the new technologies that have revolutionised and transformed the financial sector [8,9]. Therefore, financial technology applies technological innovations to financial processes, products and services [10].

In this context, technology applied to finance is being used to attract traditional banking clients, thus optimising commercial transactions, improving credit granting and marketing, as well as making banking operations more efficient [11-13]. Consequently, the technologies that allow the automation of financial services are replacing the old systems, driving a necessary and accelerated transformation process, from the application of big data, blockchain, artificial intelligence, machine learning, cryptocurrencies, biometric recognition, among others [14-17].

This has justified the interest of this research. Therefore, the motivation of this study is to document the evolution of the knowledge base of financial technologies, in relation to social, digital and economic development. In the literature reviewed, works have been found that focus on this topic, so that the research questions seek to determine (i) what is the structure of knowledge about financial technology at a global level; (ii) which are the most productive authors, research institutions and countries; and (iii) what are the thematic axes that this research topic develops and toward which they are evolving.

The main objective of this study is to analyse worldwide research on financial technology from 1975 to 2019. To acquire answers to the research questions, a sample of 2012 articles from scientific journals selected from the Elsevier's Scopus database was analysed. This study uses the bibliometric method to gather the knowledge base on financial technologies in an international context. The findings showed the contributions in this research field, so that it has allowed recognising the leading driving agents (authors, research institutions and countries), and current and future research lines.

Among the principal limitations of this research, it is to discern whether the volume of published articles is related to a certain one with the advancement of digital technologies; a certain normative regulation that affects the financial sector; to the demands of interest groups; or to the updating of the needs demanded by a global society.

Lastly, it should be noted that among the research lines that are currently being developed in relation to the subject of the research, these refer, among others, to analysing the aspects: financial, economic, technology transfer, investment, innovation, commercial and development of societies and institutions.

To achieve the stated objective, this study is organised as follows. Section 2 justifies the significance of the research field, delimiting the unit of analysis and conducting a review of the background, theoretical principles and a conceptual framework of financial technology. Section 3 details the methodology applied in this study. Section 4 displays and discusses the main findings obtained. Finally, in the last section the main conclusions are shown.

\section{Research Scope}

Section 2, after introducing the topic under investigation, contains the theoretical foundation within which this research is framed, and also provides the definition of the concepts that will be used in the development of the study, in order to avoid different interpretations. In this way, the motivation of this section is to serve as a guide for the research and to provide a theoretical and conceptual framework for the interpretation of the results.

\subsection{Backgrounds}

The evolution of financial technology is made up of a series of events in innovations at the intersection of finance and technology. Table 1 shows the main events that have occurred in this research topic since its inception. 
At the beginning of the 20th century, settlement of interbank payments was often done through the delivery of cash or gold. In 1915, the Federal Reserve banks began to move funds electronically. American banks, in 1918, created a telecommunications system to process funds transfers, connecting telephones of the Reserve, the Federal Reserve Board and the Treasury by telegraph. Hence, the Fedwire fund service emerged, an electronic fund transfer service that banks, companies and government agencies rely on to carry out transactions. Later, in 1934, the IBM 801 Bank Proof machine was introduced, and in 1949, the IBM 803 Proof machine was created to perform a set of financial services $[18,19]$.

In this line, in 1950, the Diners Club credit card, from the company Diners Club International, was formed as the first independent credit card company. Also, in 1955, computer scientist John McCarthy coined the concept 'Artificial Intelligence' (AI) to refer to the science and engineering of smart machine manufacturing; while, in 1952, A. Samuel introduced the term 'Machine learning' in 1952, and in 1957, F. Rosenblatt, based on a series of findings, gave way to its definition as an AI application that it focuses on developing computer programs to access the data and use it to learn for themselves. In this constant evolution, in 1967, J. Sheperd-Barron created the first ATM, and began operating at Barclays Bank [20,21].

Afterwards, in 1971, G. Macklinse founded NASDAQ, which would later become the second largest automated and electronic stock exchange in the United States, the first being the New York Stock Exchange. Later, in 1973, Swift (Society for Worldwide Interbank Financial Telecommunication), the international financial communications network between banks and other financial entities, was created. Years later, in 1982, E-Trade Financial Corporation (E*TRADE) emerged as an electronic commerce platform to trade financial assets, in addition to providing a set of services. In relation to financial technologies, it is attributed to J.R. Mashey, of the American manufacturer of hardware and software of computers, Silicon Graphics, Inc., the beginning of the use of the term 'Big Data' [10]. In 1993, Citicorp establishes the Financial Services Technology Consortium. Subsequently, Wells Fargo converted, in 1995, the first bank to offer an online checking account, which is currently the second largest bank in deposits, mortgage services and debit cards [22]. On the other hand, in 1997, the first mobile payment was made, by text message, when buying a soft drink from a vending machine. At the end of this decade, in 1998, M. Levchin, P. Thiel and L. Nosek founded Pay Pal, with the name of Confinity, which initially developed security software for portable devices. Moreover, in 1998, Security First Network Bank became the first online bank, founded in the United States by J. S. Mahan III. In 2000, Confinity merged with X.com, an online banking company created by E. Musk [23,24].

Subsequently, in 2008, computer developers working under the pseudonym Satoshi Nakamoto created a white paper establishing the model for a blockchain. Similarly, in 2009, S. Nakamoto implements the first blockchain for transactions made with Bitcoin. Thus, Bitcoin was created as a form of cash, which could be sent on a peer-to-peer basis without the need for a central bank or other authority to operate $[7,25]$.

In this order, in 2011, Google Pay emerged as a peer-to-peer payment service that allows money to be sent and received from a mobile device or computer at no cost to the sender or recipient. Next, in 2012, Coinbase was founded as a cryptocurrency trading platform, offering exchange services between cryptocurrencies and fiat currencies, and storage and management of digital assets. In 2014, Apple Pay was launched as a mobile payment service. Likewise, in 2014, Blockchain 2.0 technology emerged, exploring its potential for other financial and inter-organizational transactions, now without its link to currencies. In 2015, the Ethereum cryptocurrency is created from a revolutionary Blockchain technology, that is, developing decentralised applications and smart contracts. Moreover, in this same year 2015, in the United Nations Environment Program, the report "The Financial System We Need" is written, with the firm intention of making financial technology green [26,27].

Afterward, in 2016, the first Fintech bachelor's degree program was created, by the Frankfurt School of Finance and Administration, offering Digital Innovation and FinTech, in the Bachelor of Business Administration [28]. Finally, in this evolution, in 2018, Google Ventures makes the first FinTech investment [29]; and, in 2019, the EU-High-level Conference is held, with an international 
approach to sustainable finance, to confirm the global need to link the concepts of financial technologies with sustainability [30].

Table 1. Evolution of financial technology.

\begin{tabular}{lc}
\hline Year & Milestone \\
\hline 1915 & Federal Reserve banks begin to move funds electronically \\
1918 & Fedwire Funds Service \\
1934 & IBM 801 Proof Machine \\
1949 & IBM 803 Proof Machine \\
1950 & Diners Club credit card \\
1955 & Artificial Intelligence \\
1957 & Machine Learning \\
1967 & First Automated Teller Machine (ATM) \\
1971 & Fundacion de NASDAQ \\
1973 & E-Trade Financial Corporation (E×TRADE) \\
1982 & Big Data \\
1990 & Financial Services Technology Consortium \\
1993 & First bank online checking account by Wells Fargo \\
1995 & First mobile payment \\
1997 & Pay Pal (Confinity); Security First Network Bank \\
1998 & Confinity merged with X.com \\
2000 & Bitcoin \\
2009 & Google Pay Send \\
2011 & Apple Pay \\
2014 & Fociety for Worldwide Interbank Financial Telecommunication) \\
2015 & First FinTech Investment by Google Ventures \\
2016 & EinTech bachelor program by the Frankfurt School of Finance \& Management \\
2018 & High-level conference: A global approach to sustainable finance \\
2019 &
\end{tabular}

\subsection{Framework}

This research is supported by a series of theoretical principles, which together with the basic concepts define the frame of reference for global financial technology research. In addition, a set of concepts related to the subject of study have been defined, which introduce part of the concepts that will stand out in the results because of their importance and connection. On the other hand, once the literature has been reviewed, Table 2 presents the main articles that support the principal aim of this research study.

Table 2. Main literature reviewed in relation to the aim of the research topic.

\begin{tabular}{cccc}
\hline Year & Article Title [Reference] & Author(s) & Journal \\
\hline 2019 & Finance, technology and disruption [31] & An, J.; Rau, R. & $\begin{array}{c}\text { The European Journal of } \\
\text { Finance }\end{array}$ \\
\hline 2019 & $\begin{array}{c}\text { Brave New Digital World Financial Technology } \\
\text { and the Power of Information [32] }\end{array}$ & Kerényi, Á.; Müller, J. & $\begin{array}{c}\text { Financial and Economic } \\
\text { Review }\end{array}$ \\
\hline 2019 & $\begin{array}{c}\text { Do Fintech and Cryptocurrency Initiatives Make } \\
\text { Banks Less Special? [33] }\end{array}$ & Schich, S. & $\begin{array}{c}\text { Business and Economic } \\
\text { Research }\end{array}$ \\
\hline 2018 & Why Finance Needs Tech and AI [34] & Abouayoub, N. & ITNOW \\
\hline 2018 & Fintech and regtech: Impact on regulators and & Anagnostopoulos, I. & $\begin{array}{c}\text { Journal of Economics } \\
\text { and Business }\end{array}$ \\
\hline 2018 & $\begin{array}{c}\text { FinTech (Financial Technology): What is It and } \\
\text { How to Use Technologies to Create Business } \\
\text { Value in Fintech Way? [36] }\end{array}$ & Leong, K. & $\begin{array}{c}\text { International Journal of } \\
\text { Innovation, Management } \\
\text { and Technology }\end{array}$ \\
\hline 2017 & Blockchain Technology in Finance [37] & $\begin{array}{c}\text { Treleaven, P.; Gendal } \\
\text { Brown, R.; Yang, D. }\end{array}$ & Computer \\
& & & \\
\hline
\end{tabular}


Table 2. Cont.

\begin{tabular}{|c|c|c|c|}
\hline Year & Article Title [Reference] & Author(s) & Journal \\
\hline 2015 & $\begin{array}{c}\text { Introduction: Technology, Finance and Trade in } \\
\text { Emerging Markets [38] }\end{array}$ & $\begin{array}{l}\text { Kim, Y.; Cin, B.C.; } \\
\text { Cho, K.; Yi, J. }\end{array}$ & $\begin{array}{l}\text { Emerging Markets } \\
\text { Finance and Trade }\end{array}$ \\
\hline 2014 & $\begin{array}{l}\text { Socio-economic Major Risks Related to the } \\
\text { Information Technology [39] }\end{array}$ & Gaftea, V. & $\begin{array}{c}\text { Procedia Economics and } \\
\text { Finance }\end{array}$ \\
\hline 2005 & $\begin{array}{c}\text { Globalization, globalisation: Trade, technology } \\
\text { and wages [40] }\end{array}$ & Ethier, W.J. & $\begin{array}{l}\text { International Review of } \\
\text { Economics \& Finance }\end{array}$ \\
\hline 2003 & $\begin{array}{c}\text { Technology and the Infrastructure of Financial } \\
\text { Flows [41] }\end{array}$ & Kritzman, M. & International Finance \\
\hline 1999 & $\begin{array}{l}\text { The relationship between research \& } \\
\text { development expenditure and executive } \\
\text { compensation in high-technology industries [42] }\end{array}$ & Persons, O.S. & Managerial Finance, \\
\hline 1998 & Finance and the technology-trade nexus [43] & $\begin{array}{l}\text { De la Mothe, J.; } \\
\text { Paquet, G. }\end{array}$ & Technology in Society \\
\hline 1998 & $\begin{array}{l}\text { Adapting Expert System Technology to } \\
\text { Financial Management [44] }\end{array}$ & $\begin{array}{l}\text { Holsapple, C.W.; Tam, } \\
\text { K.Y.; Whinston, A.B. }\end{array}$ & Financial Management \\
\hline 1984 & $\begin{array}{l}\text { Information Technology and Financial } \\
\text { Institutions [45] }\end{array}$ & Williamson, $\mathrm{M}$. & Managerial Finance \\
\hline
\end{tabular}

The basis of financial technology is supported by theoretical principles that underlie the application of new technologies in the financial industry. The literature review has established the framework of the research field that studies companies that offer financial products and services, through information and communication technologies.

Technology research is supported by a set of theoretical principles that establish the frame of reference. Thereby, the technological and social changes lead the economy, finance and society to the need to mutate many of its categories to continue meeting its objectives.

Digitization and its phenomena, both convergence and transcoding, have brought about a new theoretical change, which also has the main characteristic of rendering other traditional management modes completely obsolete [46,47]. One of these changes refers to the collapse of traditional borders that separated communicational and informational activity (sender, message and receiver) into psychosocial dimensions [32,48,49]. This division has disappeared and its limits are blurred in the phenomena of the new technological means. Internet browsing is a means that connects the process of intrapersonal thinking, contact with the interpersonal world and that of aggregate groups in digital networks. With the technological extensions of the computer and the mobile phone, the privacy barrier disappears, identity is removed as a pillar of rationality and both private life and identity or authorship rights evolve towards a context in which they acquire a different social value.

Hence, a convergence of these spheres appears, which makes intra, interactive and massive processes merge through interpersonal technological contexts in ways that are still in the process of being defined. This change allows us to recognise the capacity of human communication to make its dimensions of action more flexible, that is, the ineffectiveness of concepts such as identity, authorship, active sender, passive receiver, in the face of phenomena such as current digital convergence $[37,40,50]$.

Below are the basics and considerations about the terms and concepts used in this research. In this context, finance corresponds to the area of Economics and Business Administration that studies the obtaining and administration of financial resources, that is, financing, saving and investment. Among the areas of study are the study of the profitability of investments, the adequate management of indebtedness, the determination of the prices of tangible and intangible assets and the maintenance under control of variations in the value of money over time [12,41,48]. In this order, traditional finance has suffered in recent decades from the impact of the Internet.

As for technology, it refers to the set of knowledge and techniques that are applied in an orderly manner to achieve a certain objective or solve a problem [51,52]. Likewise, digital technology defined 
as the application of methods to develop systems that are expressed in numbers or data, allows to automate some processes, in addition to compressing large amounts of information in small storage devices $[53,54]$.

In this order, digital transformation incorporates digital technology in all aspects and requires, for example, changes in the fields of technology, culture and operations. Thereupon, to take advantage of emerging technologies and the expansion of human activities, organisations need to reinvent themselves and transform all their processes. For this reason, it requires a change of focus and implies innovating in technology, in addition to modifying the institutional culture to ensure its development $[55,56]$.

On the other side, digital transformation is contemplated like the fourth industrial revolution, since this change is technological and involves the adoption of new skills by individuals, in addition to the reinvention of institutions. Moreover, it is also considered the third phase of the adoption of digital technologies, after digital competition and digital use $[39,57,58]$. The business fabric is being transformed by global trends, where new technologies play a prominent role, giving rise to a digital economy and new business models.

Without a doubt, one of the sectors that is driving the digital transformation process the most is the financial sector, with solutions ranging from new services for its clients, which translate into applications and Fintech services or mobile payment systems, to a change in their control and security mechanisms through the incorporation of systems such as Blockchain $[37,59,60]$.

Digitising and connecting devices have allowed tasks to be handled more quickly, efficiently and from anywhere. This expansion is completely changing the global financial system, which is seen in the increase in banking websites and companies dedicated to digital payments, online loans and crowdfunding, online brokers and electronic transfers [61,62].

In this area of knowledge, the term Fintech has been coined, which comes from the words finance and technology. This refers to financial services whose provision is linked to technological innovations. Therefore, the development of financial technology companies is having repercussions in traditional banking $[63,64]$.

Starting with digitization and Big Data, Fintech companies offer new financial solutions, such as raising capital, making payments or offering loans online, which allow entities to expand more at a lower cost, because of the elimination of an entire infrastructure of offices. As a consequence of Fintech development, the decrease in the costs of certain financial services is derived $[65,66]$.

To all this, the management, in a general way, indicates the set of actions that allow the performance of any activity. In the business or commercial context, it is associated with business administration, and seeks the efficiency and profitability of what is managed $[67,68]$.

In this environment, the management of financial technology represents the administration of innovative applications in the financial sector, with the aim of facilitating financial services to the client, with speed, transparency and security. In this way, technology is an innovation tool to improve the quality of life and socio-economic progress of society, and increase the performance, competitiveness and efficiency of financial companies [69].

\subsection{Research-Related Terminology}

In order to build an underlying conceptual structure on this topic, other concepts have been identified that form the basis of knowledge resources on financial technology. In this way, terms such as Blockchain, Bitcoin, Big Data, Artificial Intelligence, Data Management, Data Mining, Deep Learning, Business Intelligence, Digital Banking and Internet of Things are defined in the context of the research.

In this way, Blockchain concept is a shared database that functions as a book for the registration of purchase-sale operations or any other transaction, allowing the storage of information that cannot be lost, modified or deleted. By using cryptographic keys, and by being distributed by different computers, it has security advantages against manipulations and fraud [70-72]. Any type of information that needs to be preserved intact and that must remain available can be stored on the Blockchain in a 
secure, decentralised and cheaper way than through intermediaries. Its use can be applied to both the economy and health, the Internet of Things and other documents. In the context of this research, it is important to recognise that Blockchain allows to verify, validate, track and store information about money and financial transactions [73,74].

Likewise, Blockchain is generally associated with Bitcoin and other digital currencies. In this way, Bitcoin refers to the free and decentralised digital currency, cryptocurrency or electronic currency that allows direct transaction without any intermediary. It lacks the backing of a central bank or government. Blockchain is essential for the operation of bitcoin, and avoiding the falsification of a transaction [75].

In the context of this research, the Big Data concept stands out, which consists of the management and analysis of massive volumes of data that cannot be processed in a conservative way, since they exceed the limits and capabilities of the software tools generally used for data capture, management and processing. The main objective of Big Data is to transform data into information that helps in decision-making. In this way, companies use Big Data to recognise the profile and needs of the customers regarding the products and services sold [76,77]. This allows the way in which the company interacts with its customers and how they serve them to be adapted. This concept encompasses technological infrastructures and services, which have been created to provide solutions to the processing of large structured, unstructured or semi-structured data sets [78].

In the terminology of the field of study, artificial intelligence (AI) refers to the scientific field of computing that focuses on creating programs and mechanisms that can display behaviours considered intelligent. The techniques developed in the field of artificial intelligence are at the service of data management and information administration. From data cataloguing to understanding, AI offers exciting new opportunities to manage large volumes of information [79]. Among its advantages, the following stands out: (i) Automate data processing: it allows to automate routine tasks related to data (integration and administration); (ii) verify the quality of the information: it is an effective quality control system, with the objective that analytical and Big Data systems are capable of drawing reliable conclusions that help in corporate decision-making; (iii) integrate legacy data: it allows to rescue non-digitised data and convert it into systems-readable formats and store it in the cloud for further processing, optimising business intelligence; and (iv) develop rules for automated data management: help analyse data usage patterns and recommend optimal strategies for administration and storage [80-82].

In this context, data management is the advancement and execution of architectures, policies, practices and procedures that suitably manage the needs of the complete life cycle of the study data. Its purpose is to make the company's resources and investments more profitable when it comes to disposing and managing customer data $[83,84]$.

On the other hand, the term data mining obeys the set of techniques and technologies that allow large databases to be explored, automatically or semi-automatically, to find repetitive patterns that describe the behaviour of data that have been accumulated over time. Along these lines, these patterns can be found using statistics or search algorithms close to AI and neural networks, with the intention of providing information to companies to help them make future decisions [85].

While, deep learning is an aspect of AI, which is concerned with emulating the learning approach that humans use to obtain certain types of knowledge; or put another way, it is a set of machine learning algorithms that tries to model high-level abstractions level in data using computational architectures, which support multiple and iterative nonlinear transformations of data expressed in matrix or tensor form [86].

In this study, business intelligence refers to the set of strategies, applications, data, products, technologies, which are focused on the administration and creation of knowledge about the medium, through the analysis of existing data in an organisation or company, to facilitate the taking of decisions $[87,88]$. In another way digital banking is the banking that can be accessed through the 
Internet and is related to other terms such as virtual banking, online banking, e-banking or electronic banking [89].

In all this context, Internet of Things (IoT) suggests to the digital interconnection of everyday objects with the Internet, thus becoming smart objects. In other words, it is the Internet connection with objects through sensors that send and receive data in a continuous way so that, from these and their interpretation, proceed to the execution of actions. It constitutes a radical change in the quality of life of people in society, it offers a large number of new opportunities for access to data, specific services in education, security, healthcare and transportation, among other fields. It is one of the pillars of digital transformation, and one of the foundations of the digital economy and essential for sectors such as Industry 4.0, Smart City, e-Health, tourism, education, administration, entrepreneurship or cybersecurity [90-92].

\section{Materials and Methods}

\subsection{Bibliometric Method}

Scientometrics studies the resources, results and how the production of knowledge and techniques are organised. Hence, bibliometrics, as part of scientometry, applies mathematical and statistical methods to scientific literature, to analyse the activity of a certain scientific field. The science of science was started by Derek de Solla Price and Eugene Garfield in the mid-20th century, and since then it has become generalised in the analysis of scientific research, in addition to helping to review knowledge in multiple scientific disciplines $[93,94]$. It provides valuable data on the relationships between research and innovation. In this way, bibliometrics has been developed from the reflection on scientific development and the availability of numerous databases available to the researcher. On the other hand, it has become an indispensable tool for the optimal decision-making of managers and directors of organizations that develop research and innovation programs. Quantitative bibliometric-based studies enhance the understanding and description of activity dynamics and scientific production.

In a more specific sense, the methods and instruments seek the identification and treatment of the information contained in the various scientific publications, since they capture the knowledge and techniques when they are disclosed. In this process, the research activity originates from the characterisation of the study topics, the formulation of research questions, data collection, results and conclusions, and which will subsequently be published. Through this dynamism, research stands as one of the mechanisms of innovation.

Bibliometric analyses use indicators to describe scientific activity and its evolution. In this order, to measure the results of scientific activity, activity indicators are used, that is, in order to obtain data on the volume and impact of research activities, and relationship indicators, to measure interactions between thematic areas and researchers. This research analysis underlies the hypotheses, on the one hand, of measuring production and impacts, in addition to obtaining information on the relationships between researchers, funding sources and publications or patents; and, on the other hand, to identify the communities of actors that support the research activity, in order to analyse the relationships between scientists and identify the research lines and study their transformations, delimiting the borders of each group of researchers and schools of knowledge they develop [95-97]. For this purpose, it is necessary to initially establish the thematic areas and the networks of actors present in the research.

\subsection{Data Collection and Processing}

The aim of this study is to determinate the general dynamics of research on financial technology at a global level. Hence, a quantitative analysis is performed using bibliometrics. In recent years, bibliometric methodology has encouraged the revision of different schools of scientific knowledge. In this sense, it has been used in numerous scientists, including management, finance and economics [98-100]. According to the main literature reviewed on this topic, presented in Table 2, the terms chosen in the search string have been 'finance', 'technology' and 'management'. 
Mainly, the preference of the Scopus database for the analysis of the document sample is due to the fact that, when performing the initial search in the Web of Science (WoS) and Scopus databases, it showed a significant difference in the volume of articles during the period analysed (1975-2019). That is, from WoS, 624 articles were extracted, while from Scopus, 2012 articles.

Moreover, Scopus has a number of advantages over WoS, such as: (i) It is considered the largest deposit of peer-reviewed literature; (ii) it minimises the risk of losing documents during the search; (iii) it is easily accessible; (iv) it offers tools for data visualisation and analysis; (v) it allows the sample to be downloaded in different formats; and (iv) it presents a wide variety of data [101,102].

Thereby, the procedure followed to select the sample on research in financial technology is adjusted to the flow chart of Figure 1, in relation to the Preferred Reporting Elements for Systematic Reviews and Meta-Analyses (PRISMA) [103]. For this, in phase 1 (identification) 177,129 records were identified from the Scopus database, considering all the fields for each of the key search terms (finance, technology and management), all types of documents and all the data in the data range (all years-May 2020). In the next phase 2 (screening) the option of 'article title, abstract and keywords' was chosen in the field of each term, so 172,681 were excluded, so that 4448 records remained. Finally, in phase 3 (eligibility), only the articles were selected as the type of document, to guarantee the quality derived from the peer review process. Accordingly, in this phase, 2383 documents were excluded, so 2065 records were obtained.

The analysis time horizon is between 1975 and 2019, both included, that is, from the publication of the first article on this topic (1975) to the last full year (2019). For these reasons, in the last phase (included), 53 documents were excluded, so the final sample included 2012 articles.

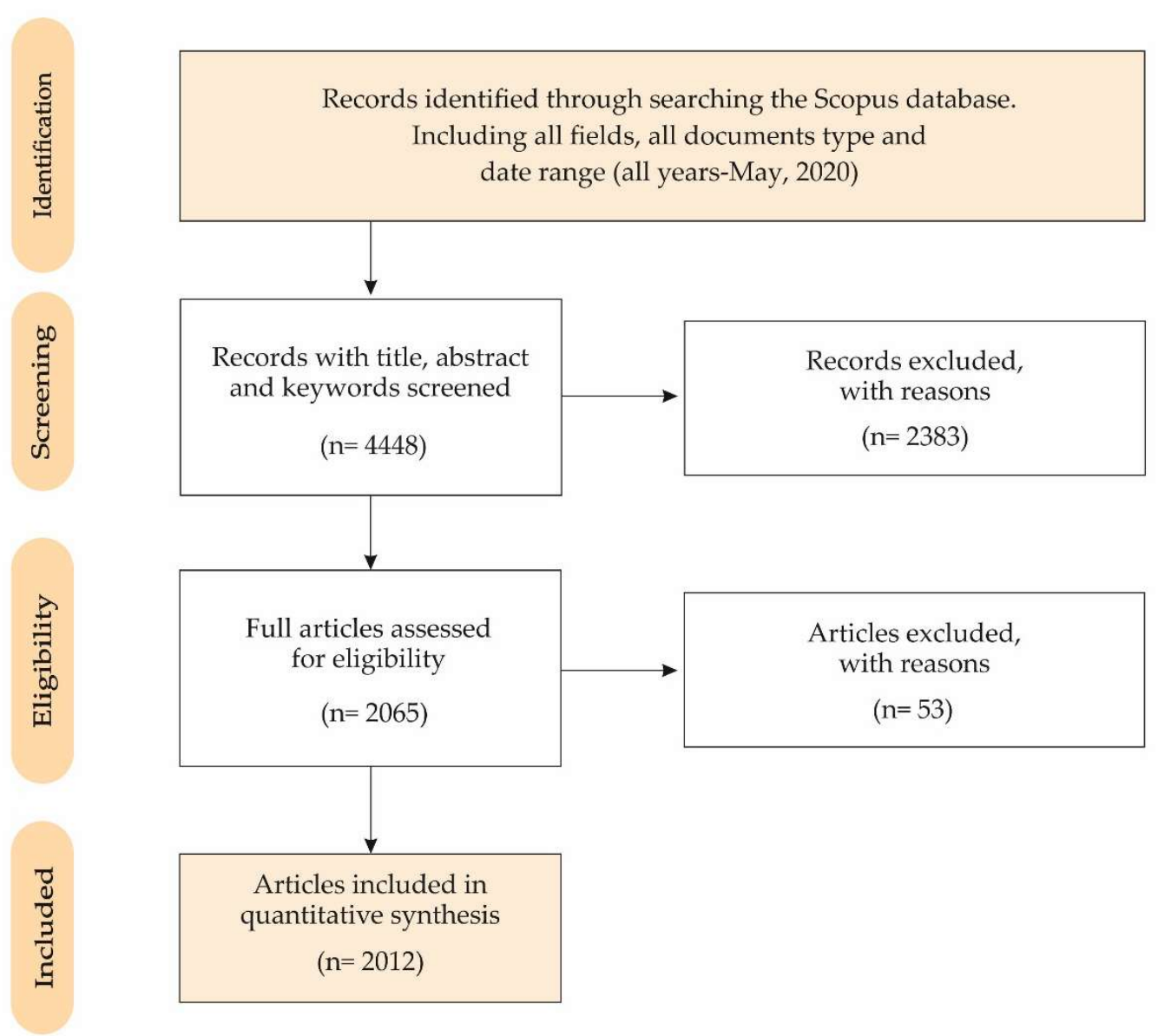

Figure 1. Document selection flowchart (PRISMA). 
Definitively, the search selected records from the subfields of title, abstract and keywords, in the period that contains the last 45 years (1975-2019). This procedure has been successfully applied in numerous studies that have used the bibliometric method [104-106].

In this research study, the scientific production indicators examined have been both the distribution by years of the published articles and the productivity of the authors, countries and research institutions.

The quality indicators used and referred to the impact of the different agents of this research topic have been: The h-index, which allows to detect which are the most outstanding authors in the discipline, based on the number of citations that have received their scientific articles [107]; the count of the number of citations; the 2018 CiteScore indicator, which is obtained from the calculation of the number of citations in a year received by academic articles published in a journal in the 3 immediately preceding years, divided by the total number of articles published during those same 3 years; the 2018 SCImago Journal Rank (SJR), which measures the quality of the scientific journals included in the Scopus database [108]; and the 2018 Source Normalised Impact per Paper (SNIP), which counts the number of citations received by a journal for three years divided by the potential citation from the journal's scientific field.

Likewise, the indicators of the collaboration structure, which measure the links between the authors, research institutions and countries, have been examined using the processing tools and network maps due to their reliability and suitability in bibliometric analysis, by co-authorship analysis. Keyword analysis has allowed the detection of the main current or future research topics, based on the co-occurrence analysis, since scientific texts can be reduced to the set of joint appearances between the words that it is made up of. Co-occurrence analysis refers to the proximity relationship of two or more terms in a unit of text. In this way, if two terms co-occur in a sentence, that is, appear together in it, it is likely that they are semantically related. Hence, in a research topic, this method allows to deduce the relevant terms and to extract the schools of thought or thematic axes. Accordingly, the network based on co-occurrence method provides a graphical visualisation of relationships of concepts represented within the documents. Therefore, co-occurrence analysis allows strongly related concepts to be grouped within the set of documents or records [109-111]. For the analysis of these relationship indicators, the software VOSviewer (version 1.6.10., Leiden University, Leiden, The Netherlands) has been applied, which provides data on interactions and the evaluation of the contents, in order to measure the activities of the research networks [112].

The results obtained are valuable both for researchers and academics, as well as financial analysts, businessmen and political-financial decision-makers since the scientific production of a field of research with repercussions on society as a whole has been evaluated.

\section{Results and Discussion}

Section 4 presents and discusses, first, the findings of the growth of scientific production in an international context on management of financial technology. Subsequently, the distribution of articles by subject area and by journal is analysed. Likewise, the results obtained from the analysis of the main keywords associated with this topic are discussed, which allow identifying the main research lines and their evolution. Finally, the results are presented on the main keywords associated with the most prolific authors, institutions and countries.

\subsection{Scientific Production}

Figure 2 displays the progress of the 2012 articles in the sample that have been detected in the search carried out in the Scopus database.

The linear trend shows that scientific production on the financial technology research has increased at a constant rate from 1980 to 2019 , that is, over a period of more than 40 years. It is observed that the value of $R^{2}$ is 0.9261 , which is a good fit of the line to the data set. Moreover, the exponential trend line denotes that the number of articles on this financial technology research increases more rapidly 
over time, in the last 45 years. This line shows its goodness with an $\mathrm{R}^{2}$ of 0.8251 . For these reasons, both trend lines show their goodness of fit since their $R^{2}$ value is close to 1 .

To understand the importance of this research topic in recent years, it is necessary to observe that during the last 3 years (2017-2019) 20.23\% of the total articles have been published (407 of 2012); on the other hand, in the last 5-year period (2015-2019), 596 contributions have been made to the research topic, which represents $29.62 \%$; and, in addition, if the period extends to the last decade (2010-2019), these amount to $44.98 \%$ (905). These results indicate the special interest and relevance it arouses in the international academic and scientific community $[113,114]$.

Likewise, to analyse the growth of research in financial technologies, it is also important to note that in the first year analysed (1975), only 1 article was published, which represents $0.05 \%$; in 1990 , 19 (0.94\%); in 2000, 60 (2.98\%); in 2010, 59 (2.93\%); while in the last year studied (2019), 147 articles were published $(7.31 \%)$.

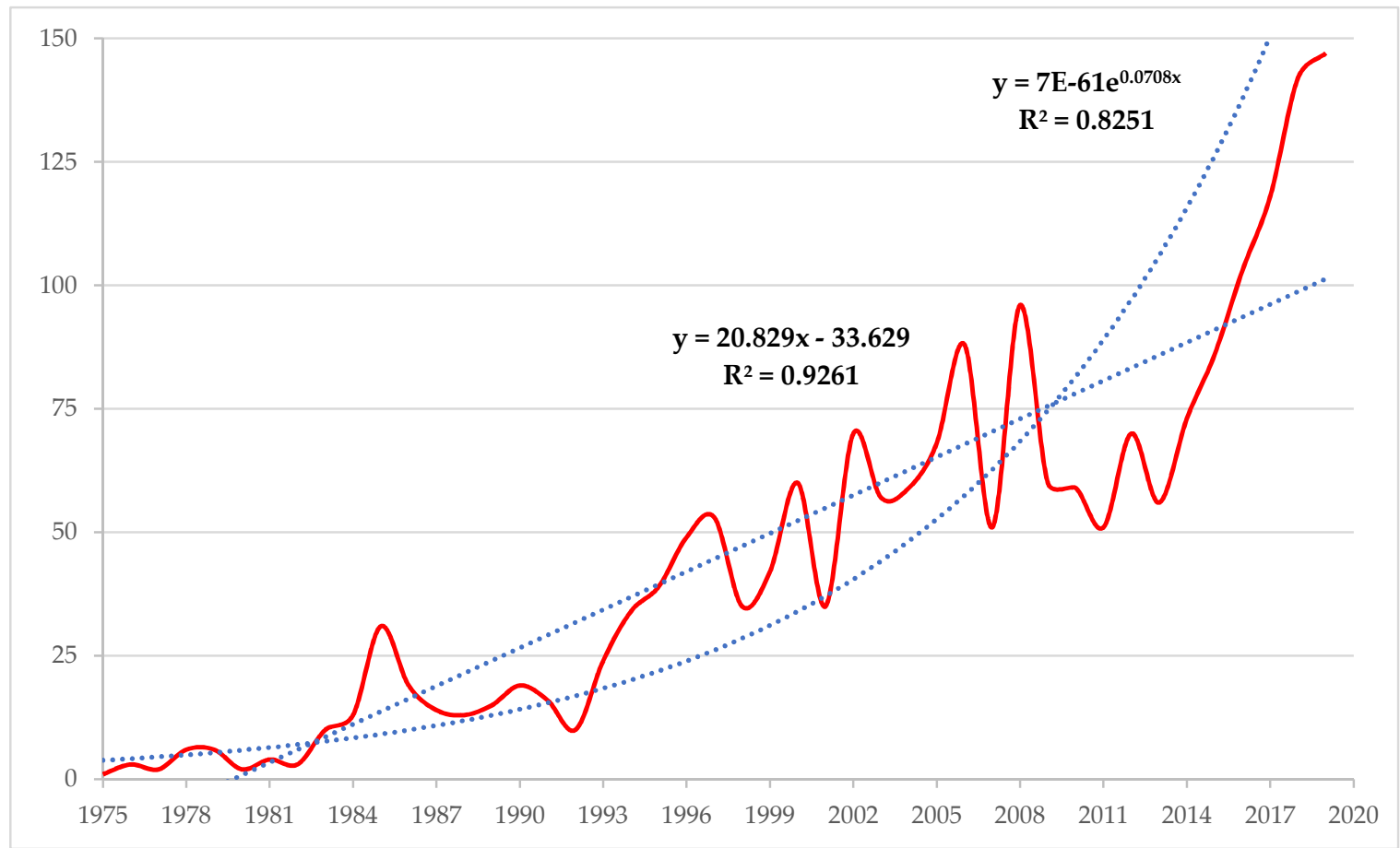

Figure 2. Evolution of the number of articles (1975-2019).

In this research topic, $92.30 \%$ of the articles are written in English (1871). This circumstance is related to the fact that the publication in this language broadens its audience, as it happens widely in the searches made in the Scopus database [115]. Furthermore, the documents have been published in other languages with less representation, such as German (30,1.48\%), Chinese (28, 1.38\%), Russian $(24,1.18 \%)$ and Spanish $(21,1.04 \%)$. The rest they do not reach $1 \%$ of the total contributions.

\subsection{Thematic Areas and Journals}

In the time horizon examined (1975-2019), articles related to financial technology research are categorised into different areas of knowledge. Hence, the 2012 articles are classified into 27 thematic areas, matching to the Scopus database. Likewise, it is necessary to emphasise that an article may be classified in more than one thematic area, depending on the interest of the author or authors of the document and the editor of the journal.

Figure 3 presents the classification of the 15 main thematic areas where articles are classified in global research on financial technology, during the period 1975-2019. Business, Management and Accounting is the category that collects the most articles, with $17.65 \%$ of the articles published (666) in the total sample. Next, it follows by Engineering $(16.43 \%, 620)$, Social Sciences $(9.97 \%, 376)$, 
Computer Science $(9.06 \%, 342)$, Medicine $(7.47 \%, 282)$, Environmental Science $(6.79 \%, 256)$, Economics, Econometrics and Finance (5.54\%, 209), Decision Sciences (5.14\%, 194), Energy (3.92\%, 148), Materials Science $(2.44 \%, 92)$ and Agricultural and Biological Sciences $(2.07 \%, 78)$. The rest of the subject areas do not reach $2 \%$ each of them of the published documents. Likewise, the 10 most relevant thematic areas group $84.42 \%$ of the articles published (3185) in the period 2004-19; while the 5 most important groups $60.59 \%$ (2286).

The study of financial technologies has been characterised by monitoring high technology and innovation, which has led to collective multidisciplinary research, although the publications have been more focused on the categories of business, management and engineering. Without a doubt, during this period, the investigation has verified the scientific and technological knowledge for the innovation, invention, development and improvement of techniques related to finance [116,117].

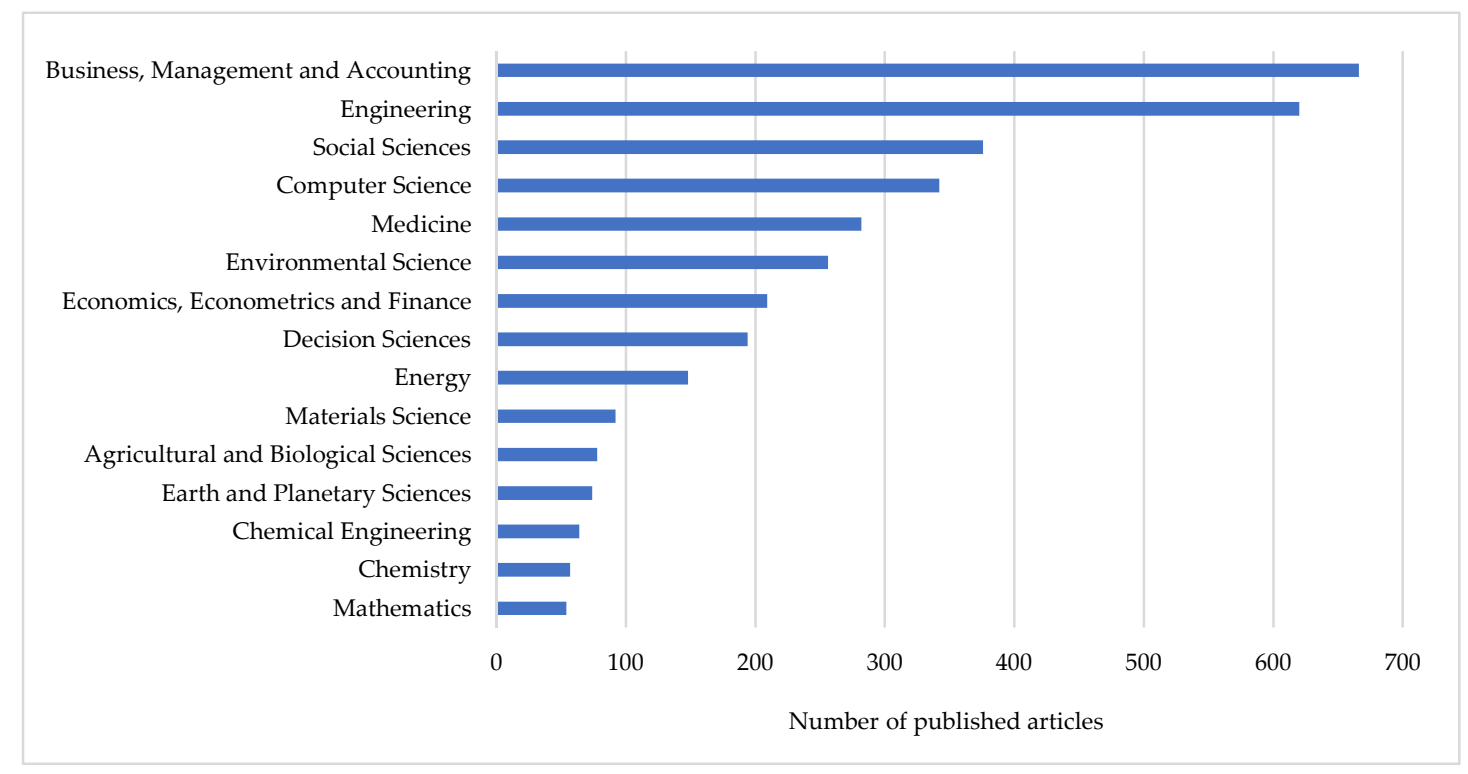

Figure 3. Top 15 thematic areas (1975-2019).

Table 3 displays the main characteristics of the 10 most prolific scientific journals on Fintech in 1975-2019 period: number of articles, number of citations for all articles, number of citations by article, $\mathrm{h}$-index in this research topic, country, thematic area, Scopus main quality indicators and year of the first and last published article. Considering the number of articles published and the percentage they represent of the total sample, this ranking is led by International Journal of Technology Management $(24 ; 1.19 \%)$ and Technovation (22; $1.09 \%)$. They are followed by, in order, Technological Forecasting And Social Change (0.89\%); Journal of Cleaner Production (0.75\%); Research Policy (0.70\%); Energy Policy $(0.60 \%)$; International Journal of Project Management $(0.60 \%)$; Long Range Planning $(0.60 \%)$; Renewable Energy (0.60\%); and IEEE Transactions on Engineering Management $(0.55 \%)$. It is observed that 9 of these journals are of European origin (6 British and 3 Dutch), and 1 American.

Likewise, it is noteworthy to indicate that Research Policy (14 articles) is the journal with the most citations (1390), and the highest average number of citations per article (99.29), bearing in mind that it is the one that covers the longest period publishing on this research topic (1976-2019, 44 years), and that classifies its articles in the categories of Decision Sciences, and Business, Management and Accounting.

In addition, the 10 journals in this ranking classify the articles in 8 different thematic areas. Thereby, Business, Management and Accounting is the one that brings together the most journals (7), which coincides with the most important for all articles (see Figure 3). It is followed by Engineering (2), and Energy (2). This shows the variety of thematic areas covered by articles on financial technology. 
Table 3. Top 10 journals (1975-2019).

\begin{tabular}{|c|c|c|c|c|c|c|c|c|c|c|c|}
\hline Journal & A & $\mathrm{C}$ & $\mathrm{C} / \mathrm{A}$ & Country & TA & $\mathbf{h}^{*}$ & CiteScore * & SJR * & SNIP * & 1st A & Last $\mathrm{A}$ \\
\hline International Journal of Technology Management & 24 & 153 & 6.38 & UK & BMA & 7 & 1.47 & 0.502 & 0.497 & 1996 & 2019 \\
\hline Technovation & 22 & 942 & 42.82 & UK & E, BMA & 14 & 6.25 & 2.300 & 2.582 & 1986 & 2006 \\
\hline Technological Forecasting and Social Change & 18 & 349 & 19.39 & Netherlands & $\mathrm{BMA}, \mathrm{P}$ & 8 & 4.32 & 1.422 & 1.745 & 1988 & 2019 \\
\hline Journal of Cleaner Production & 15 & 222 & 14.80 & Netherlands & ES, BMA & 12 & 7.32 & 1.62 & 2.308 & 2003 & 2019 \\
\hline Research Policy & 14 & 1390 & 99.29 & Netherlands & DS, BMA & 12 & 6.56 & 3.409 & 2.949 & 1976 & 2019 \\
\hline Energy Policy & 12 & 254 & 21.17 & UK & ES, EN & 7 & 5.45 & 1.988 & 1.786 & 1985 & 2019 \\
\hline International Journal of Project Management & 12 & 695 & 57.92 & UK & BMA & 9 & 6.41 & 2.203 & 2.805 & 1989 & 2018 \\
\hline Long Range Planning & 12 & 749 & 62.42 & UK & SC, EEF & 6 & 4.42 & 2.036 & 1.839 & 1978 & 2019 \\
\hline Renewable Energy & 12 & 193 & 16.08 & UK & EN & 6 & 6.19 & 1.889 & 2.075 & 1994 & 2018 \\
\hline IEEE Transactions on Engineering Management & 11 & 194 & 17.64 & USA & $\mathrm{BMA}, \mathrm{E}$ & 8 & 2.24 & 0.833 & 1.007 & 1990 & 2019 \\
\hline
\end{tabular}

A: number of articles; C: total citations; C/A: average number of citations per article; TA: Main thematic area; BMA: Business, Management and Accounting; E: Engineering; P: Psychology;

ES: Environmental Science; DS: Decision Sciences; EN: Energy; SC: Social Sciences; EEF: Economics, Econometrics and Finance; h: h-index or Hirsch index; SJR: Scimago Journal Rank

(2018); SNIP: Source Normalised Impact per Paper (2018); 1st A: first article; Last A: last article; $\left(^{*}\right)$ in this research topic. 
Moreover, Table 3 also includes the three main impact metrics offered by the Scopus database, that is, CiteScore, SCImago Journal Rank (SJR) and Source Normalised Impact per Paper (SNIP), from 2018. The journals with the highest CiteScore are Journal of Cleaner Production (7.32), Research Policy (6.56) and International Journal of Project Management (6.41). On the contrary, the journals with the highest SJR are Research Policy (3.409), Technovation (2.300) and International Journal of Project Management (2.203). The journals with the highest SNIP are Research Policy (2.303), International Journal of Project Management (2.805) and Technovation (2.300).

It is also noteworthy that 7 of the 10 most productive journals have published in the last year analysed, 2019, and 2 in 2018. This corroborates the interest that this research topic arouses in journals and editorials.

\subsection{Analysis of Keywords}

Table 4 lists, according to the Scopus database, the 20 most frequently used keywords in the 2012 articles of the analysed sample, during the period examined (1975-2019). The most prominent terms are 'Finance' (in 866 articles, 43.04\%), and 'Technology' (227, 11.28\%). These two terms, together with 'Management' $(129,6.41 \%)$, in tenth position, were considered in the search query for the Scopus database. In addition to these keywords, 'Information Technology' (210, 10.44\%) and 'Economics' $(198,9.84 \%)$ follow in importance, in third and fourth position, respectively.

Table 4. Top 20 keywords (1975-2019).

\begin{tabular}{|c|c|c|c|c|c|c|}
\hline Rank & Keyword & $\begin{array}{c}\text { Cluster } \\
\text { (See in Figure 4) }\end{array}$ & Articles & $\%$ & Link & $\begin{array}{c}\text { Total } \\
\text { Link Strength }\end{array}$ \\
\hline 1 & Finance & 1 & 866 & 43.04 & 732 & 6095 \\
\hline 3 & Information Technology & 1 & 210 & 10.44 & 371 & 1443 \\
\hline 4 & Economics & 2 & 198 & 9.84 & 539 & 1870 \\
\hline 5 & Organization and Management & 2 & 165 & 8.20 & 324 & 1297 \\
\hline 7 & Financial Management & 2 & 146 & 7.26 & 393 & 1304 \\
\hline 8 & Decision Making & 1 & 143 & 7.11 & 438 & 1254 \\
\hline 9 & Investments & 4 & 138 & 6.86 & 403 & 1290 \\
\hline 10 & Management & 1 & 129 & 6.41 & 397 & 976 \\
\hline 11 & Technology Transfer & 3 & 124 & 6.16 & 221 & 885 \\
\hline 16 & Information Management & 1 & 104 & 5.17 & 268 & 742 \\
\hline 17 & Risk Management & 1 & 104 & 5.17 & 306 & 778 \\
\hline 18 & Economic Aspect & 2 & 92 & 4.57 & 185 & 659 \\
\hline 19 & Costs & 4 & 89 & 4.42 & 323 & 816 \\
\hline 20 & Industrial Economics & 1 & 82 & 4.08 & 195 & 611 \\
\hline
\end{tabular}

$\%$ : percentage of total articles published.

The link attribute denotes the connection or relation between two keyworks, while the total link strength attribute indicates the number of publications in which two keywords appear together. Hence, the keyword 'Finance' is the one with the most links (732) and the highest total link strength (6095). It is followed by the term 'Technology' $(547,1923)$. Without considering the terms that have been used in the search for Scopus, the most prominent keywords are 'Information Technology' $(371,1443)$, 'Economics' (539, 1870), 'Organization and Management' (324, 1297), 'Project Management' $(285,1004)$, 'Financial Management' (393, 1304), 'Decision Making' (438, 1254), and 'Investments' $(403,1290)$.

Research in financial technologies has dedicated efforts to clarify how this industry should be managed so that the results are optimal at the global level $[118,119]$, and to the transfer of technology and knowledge generated in universities and research centres to the society to provide them with practical application $[120,121]$. 
Despite the fact that bibliometrics and data mining are concerned with statistical analysis of data with the purpose of discovering patterns and trends in data, in the case of bibliometrics, its object of study is communication between academics in a quantitative way, through bibliometric indicators, a relevant aspect for this research. In this context, it is a matter of past use of information, productivity of the authors in different disciplinary fields through citation studies, etc. In this way, the focus is placed on the authors and on the dating networks that are elaborated in a certain field. Although it is true that it is an external study of scientific production, bibliometric data have the advantage of flexibility and availability, which is why its application in scientific and technological research allows monitoring of technological development at various levels (university, institute or country) [122].

Figure 4 represents the network map for the keywords of the articles on Fintech, based on the co-occurrence analysis. In this Figure, the colour of the connections is used to differentiate the clusters based on the number of co-occurrences, while the size varies according to the number of repetitions. Hence, the VOSviewer software tool has detected seven main research lines developed by the different keyword communities. According to the term associated with a greater number of articles within each component, the cluster and the associated line of research are grouped under the terms 'Finance', 'Economics', 'Technology Transfer', 'Investments', 'Innovation', 'Societies and Institutions' and 'Commerce'. These terms describe the content of this field of research. For each term, the occurrences attribute is indicated, which denotes the number of documents in which a term appears, as well as the total link strength, which indicates to the number of articles in which two terms occur together.

Cluster 1 (pink), the largest and most central, groups $30.49 \%$ keywords. It is led by 'Finance' (occurrences: 866, total link strength: 6095). Table 5 includes the 50 main keywords associated with this cluster. This first thematic axis studies the financial aspects from different approaches, such as (i) technological, including AI and the Internet; (ii) management, in relation to risk management and systems management; (iii) customer satisfaction, in terms of problem solving and data security; and, (iv) the processing of financial data, which includes both accounting and financial performance [123-125].

Table 5. Cluster 1. Top 50 keywords (1975-2019).

\begin{tabular}{|c|c|c|c|c|c|c|c|}
\hline $\mathbf{R}$ & Keyword & $\mathrm{O}$ & TLS & $\mathbf{R}$ & Keyword & $\mathrm{O}$ & TLS \\
\hline 2 & Information Technology & 210 & 1443 & 27 & Managers & 29 & 278 \\
\hline 4 & Decision Making & 143 & 1254 & 29 & Industrial Research & 29 & 205 \\
\hline 5 & Management & 129 & 976 & 30 & Performance & 29 & 189 \\
\hline 6 & Industrial Management & 124 & 821 & 31 & Personnel Training & 29 & 188 \\
\hline 8 & Research and Development Management & 112 & 700 & 33 & Mathematical Models & 26 & 190 \\
\hline 9 & Risk Management & 104 & 778 & 34 & Enterprise Resource Planning & 26 & 192 \\
\hline 10 & Information Management & 104 & 742 & 35 & Manufacture & 26 & 171 \\
\hline 11 & Strategic Planning & 84 & 675 & 36 & Problem Solving & 25 & 231 \\
\hline 12 & Industrial Economics & 84 & 611 & 37 & Data Mining & 25 & 206 \\
\hline 17 & Internet & 42 & 360 & 42 & Financial Performance & 22 & 156 \\
\hline 18 & Information Systems & 41 & 319 & 43 & Regression Analysis & 21 & 173 \\
\hline 19 & Product Development & 37 & 321 & 44 & Contracts & 21 & 161 \\
\hline 20 & Management Information Systems & 37 & 285 & 45 & Decision Support Systems & 20 & 184 \\
\hline 21 & Sales & 34 & 316 & 46 & Big Data & 20 & 95 \\
\hline 22 & Supply Chain Management & 34 & 196 & 47 & Artificial Intelligence & 19 & 209 \\
\hline 23 & Computer Software & 33 & 285 & 48 & Computer Networks & 18 & 243 \\
\hline 24 & Customer Satisfaction & 32 & 302 & 49 & Benchmarking & 18 & 140 \\
\hline 25 & Budget Control & 31 & 239 & 50 & Software & 18 & 147 \\
\hline
\end{tabular}

R: rank position; O: occurrences; TLS: total link strength. 
Cluster 2 (green) brings together $26.41 \%$ of the keywords. It is headed by "Economics" (occurrences: 198, total link strength: 1870). Table 6 contains the 50 main keywords associated with this cluster. This second component is associated with the economy, that is, it is dedicated to examining the economic aspects and the statistical and management processes that allow an organisation to obtain economic and operational improvements. It includes terms such as cost-benefit analysis, capital financing and capital expenditures [126,127].

Table 6. Cluster 2. Top 50 keywords (1975-2019).

\begin{tabular}{lccccccc}
\hline $\mathbf{R}$ & Keyword & O & TLS & $\mathbf{R}$ & Keyword & O & TLS \\
\hline 1 & Organization and Management & 1297 & 165 & 26 & Review & 131 & 19 \\
2 & Financial Management & 1304 & 144 & 27 & Questionnaire & 191 & 18 \\
3 & Economic Aspect & 659 & 88 & 28 & Costs and Cost Analysis & 199 & 17 \\
4 & Methodology & 617 & 75 & 29 & Leadership & 182 & 17 \\
5 & Education & 447 & 62 & 30 & Comparative Study & 119 & 17 \\
6 & Short Survey & 349 & 52 & 31 & Financing, Government & 163 & 16 \\
7 & Resource Allocation & 359 & 39 & 32 & Capital Expenditures & 147 & 16 \\
8 & Organization & 407 & 37 & 33 & Geographic Distribution & 121 & 16 \\
9 & Government & 414 & 36 & 34 & Legal Aspect & 106 & 15 \\
10 & Cost & 343 & 32 & 35 & Motivation & 133 & 14 \\
11 & Forecasting & 263 & 32 & 36 & Total Quality Management & 143 & 14 \\
12 & Cost-Benefit Analysis & 295 & 30 & 37 & Communication & 119 & 14 \\
13 & Procedures & 342 & 28 & 38 & Decision Making, & 133 & 14 \\
14 & Quality Control & 269 & 28 & 39 & Organizational & 104 & 14 \\
15 & Information System & 229 & 28 & 40 & Purchasing & Risk & 14 \\
16 & Cost Control & 214 & 26 & 41 & Financial Management, & 116 & 14 \\
17 & Commercial Phenomena & 310 & 25 & 42 & Hospital & 96 & 14 \\
18 & Funding & 259 & 24 & 43 & Capital Financing & 102 & 13 \\
19 & Resource Management & 185 & 23 & 44 & Social Aspect & 92 & 13 \\
20 & Budget & 181 & 23 & 45 & Publication & 145 & 12 \\
21 & Standard & 170 & 22 & 46 & Statistics and Numerical Data & 146 & 12 \\
22 & Statistics & 224 & 21 & 47 & Interview & 145 & 12 \\
23 & Information Processing & 206 & 21 & 48 & Public Relations & 107 & 12 \\
24 & Cost Effectiveness Analysis & 188 & 20 & 49 & Personnel Management & 98 & 12 \\
25 & Politics & 152 & 19 & 50 & Budgets & 102 & 12 \\
\hline & & R: rank position; O: occurrences; TLS: total link strength. & &
\end{tabular}

Cluster 3 is made up of $16.56 \%$ of the keywords and is headed by "Technology Transfer" (occurrences: 124, total link strength: 885). Table 7 incorporates the 50 main keywords associated with this cluster. This research line, linked to cluster 3, is dedicated to analysing the impact of technology transfer, and its relationship with a more sustainable society. In this sense, the scientific production of this thematic axis deals with the responsible and sustainable use of technology, considering the direct impact it has on the social, economic and environmental spheres of the community. It includes terms such as economic and social effects, environmental management, environmental impact, climate change, environmental planning and environmental technology [128,129].

Table 7. Cluster 3. Top 50 keywords (1975-2019).

\begin{tabular}{cccccccc}
\hline $\mathbf{R}$ & Keyword & O & TLS & $\mathbf{R}$ & Keyword & O & TLS \\
\hline 1 & Sustainable Development & 697 & 81 & 26 & Theoretical Model & 165 & 10 \\
2 & Developing Countries & 640 & 67 & 27 & Models, Theoretical & 164 & 10 \\
3 & Research & 520 & 58 & 28 & Socioeconomics & 154 & 10 \\
4 & Economic and Social Effects & 394 & 48 & 29 & Strategic Approach & 113 & 10 \\
5 & Developing Country & 448 & 47 & 30 & Learning & 101 & 10 \\
6 & Environmental Protection & 433 & 39 & 31 & Governance & 56 & 10 \\
7 & Cost Effectiveness & 319 & 39 & 32 & Behavioural Research & 62 & 10 \\
\hline
\end{tabular}


Table 7. Cont.

\begin{tabular}{cccccccc}
\hline $\mathbf{R}$ & Keyword & O & TLS & $\mathbf{R}$ & Keyword & O & TLS \\
\hline 8 & Surveys & 286 & 35 & 33 & Capacity Building & 66 & 10 \\
9 & International Cooperation & 283 & 35 & 34 & Incentive & 119 & 9 \\
10 & Environmental Impact & 317 & 34 & 35 & Organizations & 103 & 9 \\
11 & Environmental & 298 & 32 & 36 & Financial Provision & 54 & 9 \\
12 & Management & 194 & 28 & 37 & Local Government & 55 & 9 \\
13 & Climate Change & 171 & 25 & 38 & Trends & 97 & 8 \\
14 & Ecchnology Adoption & 241 & 23 & 39 & Environmental Monitoring & 102 & 8 \\
15 & Developing World & 200 & 21 & 40 & Demography & 100 & 8 \\
16 & Financial Services & 127 & 20 & 41 & Economic Factors & 142 & 8 \\
17 & Environmental Technology & 156 & 18 & 42 & Program Evaluation & 81 & 8 \\
18 & Environmental Economics & 157 & 17 & 43 & Quantitative Analysis & 76 & 8 \\
19 & Logistics & 130 & 16 & 44 & Environmental Planning & 67 & 8 \\
20 & Environmental Policy & 120 & 16 & 45 & GIS-Geographic Information System & 57 & 8 \\
21 & Development & 87 & 15 & 46 & Corporate Strategy & 55 & 8 \\
22 & Stakeholder & 114 & 14 & 47 & Demand-Side Management & 58 & 8 \\
23 & Performance Assessment & 110 & 14 & 48 & Environmental Performance & 68 & 8 \\
24 & Developed Countries & 116 & 11 & 49 & Microfinance & 47 & 8 \\
25 & Adaptive Management & 56 & 11 & 50 & Financial Incentives & 101 & 7 \\
\hline
\end{tabular}

R: rank position; O: occurrences; TLS: total link strength.

Cluster 4 (yellow) is led by 'Investments' (occurrences: 138, total link strength: 1290), and groups $10.78 \%$ of the keywords. Table 8 includes the 50 main key terms associated with this cluster. This fourth research line studies investments and the actors involved. This component develops the scientific production on profitability, economic analysis and optimization of investments. It also includes terms such as public-private partnership, planning and sustainability to support financial actions [130].

Table 8. Cluster 4. Top 50 keywords (1975-2019).

\begin{tabular}{|c|c|c|c|c|c|c|c|}
\hline $\mathbf{R}$ & Keyword & $\mathbf{O}$ & TLS & $\mathbf{R}$ & Keyword & $\mathbf{O}$ & TLS \\
\hline 1 & Costs & 816 & 89 & 26 & Uncertainty & 76 & 9 \\
\hline 2 & Investment & 768 & 81 & 27 & Numerical Model & 127 & 8 \\
\hline 3 & Planning & 571 & 56 & 28 & Life Cycle Analysis & 129 & 8 \\
\hline 4 & Cost Benefit Analysis & 438 & 47 & 29 & Analysis & 110 & 8 \\
\hline 5 & Sustainability & 305 & 37 & 30 & Operations Technology & 92 & 8 \\
\hline 6 & Optimization & 223 & 22 & 31 & Building & 84 & 8 \\
\hline 7 & Life Cycle & 213 & 21 & 32 & Computer Systems & 78 & 8 \\
\hline 8 & Economic Analysis & 240 & 19 & 33 & Production & 61 & 8 \\
\hline 9 & Profitability & 193 & 17 & 34 & Economic Evaluation & 81 & 7 \\
\hline 10 & Privatization & 136 & 16 & 35 & Power Generation & 68 & 7 \\
\hline 11 & Cost Analysis & 138 & 15 & 36 & Project Assessment & 59 & 7 \\
\hline 12 & Management Practice & 109 & 14 & 37 & Real Options & 70 & 7 \\
\hline 13 & Computer Simulation & 111 & 14 & 38 & Earnings & 67 & 6 \\
\hline 14 & Sensitivity Analysis & 161 & 12 & 39 & Monte Carlo Methods & 75 & 6 \\
\hline 15 & Build Operate Transfers & 116 & 11 & 40 & Stochastic Systems & 54 & 6 \\
\hline 16 & Statistical Model & 135 & 10 & 41 & Economic Conditions & 39 & 6 \\
\hline 17 & Modelling & 95 & 10 & 42 & Internal Rate of Return & 80 & 5 \\
\hline 18 & Public Private Partnerships & 94 & 10 & 43 & Feasibility Study & 76 & 5 \\
\hline 19 & Project Finance & 69 & 10 & 44 & Geographic Information Systems & 56 & 5 \\
\hline 20 & Profit & 121 & 9 & 45 & Academic Research & 55 & 5 \\
\hline 21 & Governance Approach & 109 & 9 & 46 & Life Cycle Assessment & 78 & 4 \\
\hline 22 & Energy Resource & 111 & 9 & 47 & Calculation & 53 & 4 \\
\hline 23 & Public-Private Partnership & 92 & 9 & 48 & Economic Feasibilities & 57 & 4 \\
\hline 24 & Simulation & 88 & 9 & 49 & Uncertainty Analysis & 44 & 4 \\
\hline 25 & Scheduling & 97 & 9 & 50 & Energy Consumption & 39 & 4 \\
\hline
\end{tabular}

R: rank position; O: occurrences; TLS: total link strength. 
Cluster 5 (violet) is made up of $5.78 \%$ of the key terms and is headed by 'Innovation' (occurrences: 77, total link strength: 560). Table 9 contains the top 40 key terms associated with this cluster. This fifth component is associated with the research of financial technology innovation, that is, it is dedicated to recognising the possibilities offered by knowledge, research and development to the financial system. It includes terms such as globalisation, entrepreneurship, human capital and interdisciplinary approach as cross-cutting issues for its success and development [131,132].

Table 9. Cluster 5. Top 40 keywords (1975-2019).

\begin{tabular}{|c|c|c|c|c|c|c|c|}
\hline $\mathbf{R}$ & Keyword & $\mathbf{O}$ & TLS & $\mathbf{R}$ & Keyword & $\mathbf{O}$ & TLS \\
\hline 1 & Knowledge Management & 295 & 46 & 21 & Entrepreneur & 69 & 8 \\
\hline 2 & Research And Development & 263 & 31 & 22 & Human Capital & 39 & 8 \\
\hline 3 & Financial System & 154 & 21 & 23 & Competitiveness & 64 & 7 \\
\hline 4 & Venture Capital & 105 & 21 & 24 & Technological Change & 54 & 7 \\
\hline 5 & Knowledge & 180 & 20 & 25 & Financial Crisis & 50 & 7 \\
\hline 6 & Technological Development & 152 & 20 & 26 & Joint Venture & 69 & 6 \\
\hline 7 & Financing & 135 & 19 & 27 & High Technology Industry & 49 & 6 \\
\hline 8 & Science And Technology & 137 & 17 & 28 & Industrial Investment & 53 & 6 \\
\hline 9 & Engineering Research & 104 & 17 & 29 & Innovation Management & 38 & 6 \\
\hline 10 & Recycling & 128 & 15 & 30 & Technology Policy & 37 & 6 \\
\hline 11 & Banking & 85 & 15 & 31 & Interdisciplinary Approach & 48 & 5 \\
\hline 12 & Technological Innovation & 103 & 13 & 32 & Cluster Analysis & 42 & 5 \\
\hline 13 & Entrepreneurship & 93 & 13 & 33 & Diffusion & 36 & 5 \\
\hline 14 & Capital & 154 & 12 & 34 & History & 44 & 5 \\
\hline 15 & Financial Market & 79 & 10 & 35 & Historical Perspective & 40 & 4 \\
\hline 16 & Industrial Performance & 75 & 10 & 36 & Competition (Economics) & 33 & 4 \\
\hline 17 & Manufacturing & 46 & 10 & 37 & Legislation & 30 & 4 \\
\hline 18 & Globalization & 39 & 10 & 38 & History, 20th Century & 37 & 4 \\
\hline 19 & Knowledge Transfer & 56 & 10 & 39 & University Sector & 27 & 4 \\
\hline 20 & Commercialization & 88 & 9 & 40 & Subsidy System & 41 & 3 \\
\hline
\end{tabular}

Cluster 6 (blue) groups $4.99 \%$ of the keywords and is led by "Societies and Institutions" (occurrences: 108, total link strength: 830). Table 10 incorporates the top 30 key terms associated with this cluster. The research line linked to cluster 6 is dedicated to societies and institutions, and deals with an analysis of the impact of policies and their processes on society and institutions. Financial markets, energy resources and environmental risks are interrelated and act directly on environmental issues, such as global warming and risk perception. In this sense, the scientific production of this thematic axis deals with both the direct impact of policies on nature and the use of natural resources and the generation of waste [133,134].

Table 10. Cluster 6. Top 30 keywords (1975-2019).

\begin{tabular}{cccccccc}
\hline $\mathbf{R}$ & Keyword & O & TLS & R & Keyword & O & TLS \\
\hline 1 & Public Policy & 461 & 60 & 16 & Financial Institutions & 63 & 6 \\
2 & Energy Management & 220 & 35 & 17 & Implementation Process & 53 & 6 \\
3 & Risk Analysis & 386 & 32 & 18 & Industrial Plants & 56 & 6 \\
4 & European Union & 137 & 15 & 19 & Resource Development & 40 & 6 \\
5 & Professional Aspects & 134 & 14 & 20 & Elsevier (Co) & 103 & 5 \\
6 & Risks & 133 & 14 & 21 & Probability & 50 & 5 \\
7 & Energy Resources & 94 & 12 & 22 & Decision Making Process & 37 & 5 \\
8 & Environmental Engineering & 109 & 11 & 23 & Energy Planning & 33 & 5 \\
9 & Financial Markets & 72 & 11 & 24 & Information & 31 & 5 \\
10 & Technical Presentations & 61 & 10 & 25 & Project Evaluation & 33 & 5 \\
11 & Social Aspects & 80 & 9 & 26 & Energy Security & 46 & 4 \\
12 & Risk Perception & 94 & 8 & 27 & Private Sectors & 42 & 3 \\
13 & Monitoring & 55 & 8 & 28 & Environmental Risks & 40 & 3 \\
14 & Petroleum Industry & 54 & 7 & 29 & Billion (Co) & 31 & 3 \\
15 & Global Warming & 61 & 6 & 30 & Scientist & 44 & 2 \\
\hline
\end{tabular}

R: rank position; O: occurrences; TLS: total link strength. 
Finally, cluster 7 (orange), the least numerous along with cluster 6 , is made up of $4.99 \%$ of the key terms and is headed by 'Commerce' (occurrences: 56, total link strength: 476). Table 11 lists the top 30 key terms associated with this cluster. This seventh research line studies commerce attending to aspects such as modernisation, productivity, industrial development and standardisation. The scientific production of this thematic axis deals with, from the legal frameworks, to legal obligations, legal regulations and environmental regulations $[135,136]$.

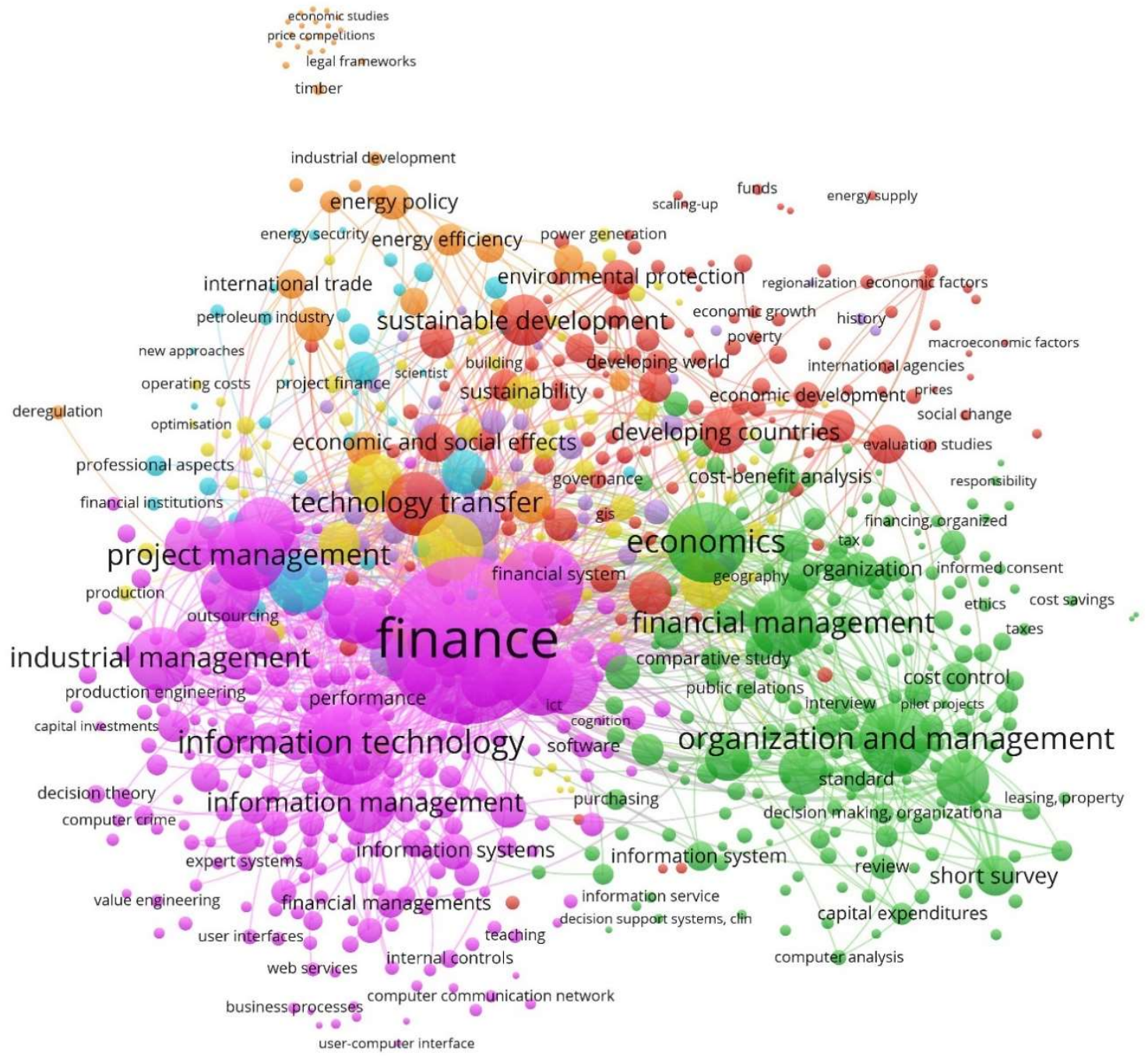

Figure 4. Network of keywords based on co-occurrence method (1975-2019).

In short, these seven thematic axes bring together all the concepts related to the investigation of financial technology during the analysis period (1975-2019), since it includes the different approaches that have been analysed by the actors that make up this field of study, that is, researchers, research institutions, countries and financing institutions. 
Table 11. Cluster 7. Top 30 keywords (1975-2019).

\begin{tabular}{cccccccc}
\hline $\mathbf{R}$ & Keyword & O & TLS & $\mathbf{R}$ & Keyword & O & TLS \\
\hline 1 & Productivity & 299 & 38 & 16 & Deregulation & 42 & 7 \\
2 & Laws and Legislation & 323 & 38 & 17 & Environmental Regulations & 88 & 5 \\
3 & Energy Policy & 274 & 37 & 18 & Timber & 60 & 4 \\
4 & Energy Efficiency & 322 & 32 & 19 & Legal Frameworks & 53 & 2 \\
5 & Eurasia & 208 & 28 & 20 & Positive Effects & 56 & 2 \\
6 & International Trade & 229 & 28 & 21 & Production Costs & 53 & 2 \\
7 & Europe & 254 & 27 & 22 & Conversion Efficiency & 47 & 1 \\
8 & Efficiency & 203 & 24 & 23 & Economic Studies & 47 & 1 \\
9 & Modernization & 158 & 15 & 24 & Foreign Markets & 47 & 1 \\
10 & Income & 189 & 14 & 25 & Foreign Trade & 47 & 1 \\
11 & Market & 198 & 13 & 26 & International Scales & 47 & 1 \\
12 & Regional Planning & 119 & 12 & 27 & Legal Obligations & 47 & 1 \\
13 & Standardization & 133 & 10 & 28 & Legal Regulations & 47 & 1 \\
14 & New Technologies & 90 & 7 & 29 & Long Terms & 47 & 1 \\
15 & Industrial Development & 80 & 7 & 30 & Low Productivities & 47 & 1 \\
\hline
\end{tabular}

R: rank position; O: occurrences; TLS: total link strength.

\subsection{Authors, Research Institutions and Countries}

Table 12 shows the main characteristics of the ten most prolific authors in this research topic. The sample of articles has been written by 4496 authors.

Thereby, the ten most productive authors and the research institutions to which they are affiliated were Kauffman (R.J. Singapore Management University); Lindelöf, P. (Södertörn University); Löfsten, H. (Chalmers University of Technology); Maebashi, I.; Maeda, M.; and Mitsuda, Y. (University of Tokyo); Negishi, M. and Nishizawa, M. (Research Organization of Information and Systems National Institute of Informatics); Nomura, H. (Nagoya University, Department of Molecular Design and Engineering); and Peffers, K. (Lee Business School). By region, 7 authors of this ranking are Asian origin (6 Japanese and 1 Singaporean), 2 Swedish and 1 American.

Table 12. Top 10 Authors: main thematic areas and keywords (1975-2019).

\begin{tabular}{|c|c|c|c|c|c|c|c|}
\hline Author & A & Country & h & TA & Keyword 1 & Keyword 2 & Keyword 3 \\
\hline $\begin{array}{l}\text { Kauffman, } \\
\text { R.J. }\end{array}$ & 4 & Singapore & 4 & $\begin{array}{l}\text { BMA, CS, } \\
\text { DS }\end{array}$ & Finance & Decision Support & $\begin{array}{l}\text { Information } \\
\text { Technology }\end{array}$ \\
\hline $\begin{array}{l}\text { Lindelöf, } \\
\text { P. }\end{array}$ & 4 & Sweden & 4 & BMA, E, CS & $\begin{array}{c}\text { New } \\
\text { Technology-based } \\
\text { Firms }\end{array}$ & Finance & Financing \\
\hline Löfsten, $\mathrm{H}$. & 4 & Sweden & 4 & BMA, E, CS & $\begin{array}{c}\text { New } \\
\text { Technology-based } \\
\text { Firms }\end{array}$ & Finance & Financing \\
\hline $\begin{array}{l}\text { Maebashi, } \\
\text { I. }\end{array}$ & 4 & Japan & 1 & CS & Finance & $\begin{array}{c}\text { Research and Development } \\
\text { Management }\end{array}$ & Education \\
\hline Maeda, M. & 4 & Japan & 1 & CS & Finance & $\begin{array}{c}\text { Research and Development } \\
\text { Management }\end{array}$ & Education \\
\hline $\begin{array}{l}\text { Mitsuda, } \\
\text { Y. }\end{array}$ & 4 & Japan & 1 & CS & Finance & $\begin{array}{c}\text { Research and Development } \\
\text { Management }\end{array}$ & Education \\
\hline $\begin{array}{l}\text { Negishi, } \\
\text { M. }\end{array}$ & 4 & Japan & 1 & CS & Finance & $\begin{array}{c}\text { Research and Development } \\
\text { Management }\end{array}$ & Education \\
\hline $\begin{array}{l}\text { Nishizawa, } \\
\text { M. }\end{array}$ & 4 & Japan & 1 & CS & Finance & $\begin{array}{c}\text { Research and Development } \\
\text { Management }\end{array}$ & Education \\
\hline $\begin{array}{l}\text { Nomura, } \\
\mathrm{H} .\end{array}$ & 4 & Japan & 1 & CS & Finance & $\begin{array}{c}\text { Research and Development } \\
\text { Management }\end{array}$ & Education \\
\hline Peffers, K. & 4 & USA & 4 & CS, DS & Finance & Commerce & $\begin{array}{c}\text { Financial } \\
\text { Services Industry }\end{array}$ \\
\hline
\end{tabular}

A: number of articles; $h$ : h-index or Hirsch index in financial technology research; TA: main thematic areas; BMA: Business, Management and Accounting; CS: Computer Science; DS: Decision Sciences; E: Engineering. 
Computer Science is the main subject area where the articles of the ten most productive authors are classified; followed by Business, Management and Accounting; Decision Sciences; and Engineering.

Furthermore, the most used keyword in the articles written by authors of this ranking is 'Finance', which is used by everyone, 8 in the first position, those of Asian and American origin, and 2 in second place, those of Swedish origin. It is followed, in order of importance, by 'Research and Development Management' and 'Education', used by the 6 Japanese authors in second and third position, respectively. It also highlights 'New Technology-based Firms' used by the 2 Swedish authors in the first position; and others related to the financial aspect of the subject, such as 'Financing' and 'Financial Services Industry'. The publications of the main authors are linked to the thematic axes that analyse the financial, economic, innovation and commercial aspects of the research.

Figure 5 displays the cooperation map between the authors, based on co-authorship analysis, who have published worldwide on Fintech. The colour of each component is linked with the group of authors in the publication of articles, while the diameter of the circle indicates the number of articles by the author. In consequence, the authors are associated to six clusters. The network shows a great dispersion in the association of authors by co-authorship, during the period analysed (1975-2019).

Cluster 1 (pink) groups 25.22\%, and presents the collaboration between Bracey, P.; Chen, J.; Gunatilake, H.; Guo, Z.; Hasan, R.; Huang, B.; Huang, W.; Jia, A.; Jiang, Y.; Khan, M.E.; Khor, N.; Lagman-Martin, A.S.; Niimi, Y.; Sun, L.; Wang, W.; Wang, X.; and Wei, Y., among others.

Cluster 2 (green) brings together $23.48 \%$ of authors, and contains the cooperation by, among others, Chen, H.; Fu, S.; Gao, J.; Huo, D.; Jiang, S.; Li, D.; Li, J.W.; Roy, R.; Shen, X.J.; Sun, G.; Wan, S.; Wen, T.; Xie, R.; Yang, S.L.; and Zhou, H.

Cluster 3 (red) groups 20.00\% and is composed by authors like Bi, Y.; Cui, Y.; Gao, C.; Guo, J.; Liu, C.; Meng, H.; Niyato, D.; Sun, N.; Wang, H.; Wang, X.L.; Xie, F., and Yu, J., among others.

Cluster 4 (yellow) links $19.13 \%$ and presents the collaboration of, among others, Chan, F.T.S.; Fei, S.; He, H.; Hsu, C.-F.; Hu, X.; Huang, S.Y.; Jin, M.; Lin, F.; Liu, Y.; Ruan, J.; Schoenherr, T.; Shi, B.; Shi, Y.; Tsai, S.-B.; Wang, N.; Wu, C.; Xu, X.; Zhao, M.; and Zhu, F.

Cluster 5 (violet) links $6.96 \%$ of the authors and presents the cooperation of, among others, Baset, S.; Dillenberger, D.N.; Ford, D.L.; Hull, R.; Laredo, J.; Novotny, P.; Vaculin, R.; and Zhang, Q.

Finally, Cluster 6 (blue) links 5.22\% and describes the collaboration of, among others, Chu, C.; Gao, S.; Tang, Z.; Todo, Y.; Wang, J.; and Zhou, T.

On the other hand, it is noteworthy that in component 4,40.91\% of the authors joined in 2019; followed by cluster $3(30.43 \%)$, cluster 1 (20.69\%) and cluster $2(14.81 \%)$. Both the United States and Japan stand out for innovation and research in technologies that involve processes of disruption and transformation in the financial sector. These two world powers address studies, publications related to innovation and financial technology [31,137,138].

The 2012, articles on financial technology research have been written in 3338 international affiliations. Table 13 displays the 10 most prolific research institutions in this topic. This ranking highlights that 7 are of American origin (The World Bank; Massachusetts Institute of Technology; Harvard University; Columbia University in the City of New York; Harvard Medical School, Purdue University; and Harvard Business School) and 3 British (London School of Economics and Political Science; Cranfield University; and University College London).

Business, Management and Accounting is the subject area where articles from the 10 most productive research institutions are most classified, in the same way that it happens for all the articles in the sample. In order of importance, Engineering follows, and the group of thematic areas: Environmental Science, Computer Science, Social Sciences. They are also grouped, although less important, in Medicine; Agricultural and Biological Sciences; Economics, Econometrics and Finance; Health Professions; and Decision Sciences. 


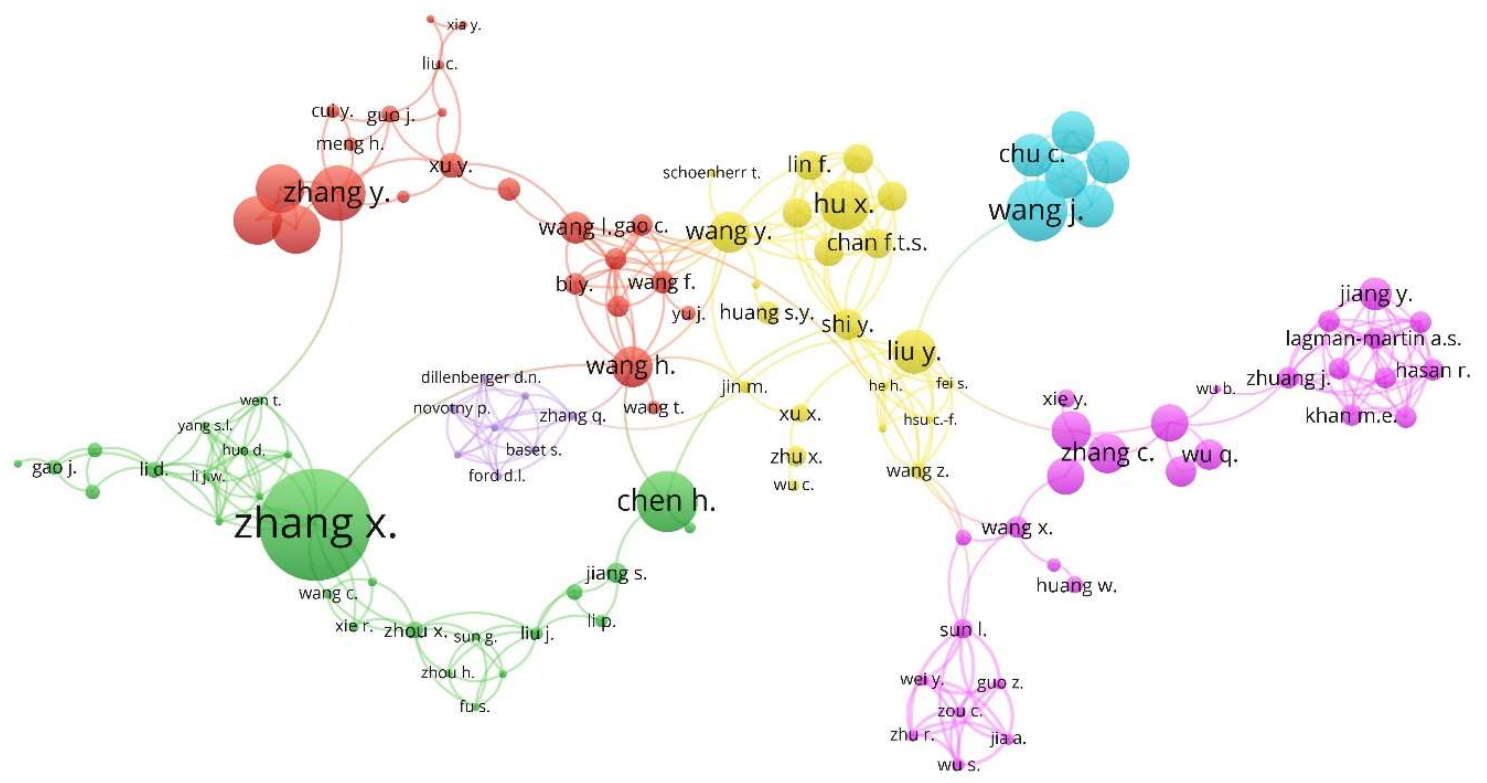

Figure 5. Network of authors based on co-authorship method (1975-2019).

Table 13. Top 10 research institutions: main thematic areas and keywords (1975-2019).

\begin{tabular}{|c|c|c|c|c|c|c|}
\hline Institution & Article & Country & $\begin{array}{l}\text { Thematic } \\
\text { Area }\end{array}$ & Keyword 1 & Keyword 2 & Keyword 3 \\
\hline The World Bank & 12 & USA & $\mathrm{ES}, \mathrm{M}, \mathrm{ABS}$ & Finance & $\begin{array}{l}\text { Developing } \\
\text { Country }\end{array}$ & $\begin{array}{l}\text { Economic } \\
\text { Aspect }\end{array}$ \\
\hline $\begin{array}{c}\text { London School of } \\
\text { Economics and Political } \\
\text { Science }\end{array}$ & 11 & UK & $\begin{array}{l}\text { BMA, EEF, } \\
\quad \text { CS }\end{array}$ & Finance & $\begin{array}{l}\text { Societies and } \\
\text { Institutions }\end{array}$ & $\begin{array}{l}\text { Decision } \\
\text { Making }\end{array}$ \\
\hline $\begin{array}{c}\text { Massachusetts Institute of } \\
\text { Technology }\end{array}$ & 11 & USA & BMA, E, CS & Finance & Technology & Biotechnology \\
\hline Harvard University & 10 & USA & BMA, E. SS & Finance & $\begin{array}{l}\text { Information } \\
\text { Technology }\end{array}$ & Marketing \\
\hline $\begin{array}{c}\text { Columbia University in the } \\
\text { City of New York }\end{array}$ & 10 & USA & E, SS, BMA & Risk Assessment & $\begin{array}{l}\text { Build Operate } \\
\text { Transfers }\end{array}$ & Finance \\
\hline Harvard Medical School & 9 & USA & $\mathrm{M}, \mathrm{E}, \mathrm{H}$ & $\begin{array}{l}\text { Organization } \\
\text { and } \\
\text { Management }\end{array}$ & $\begin{array}{l}\text { Decision } \\
\text { Making }\end{array}$ & Finance \\
\hline Cranfield University & 9 & UK & $\mathrm{B}, \mathrm{E}, \mathrm{ES}$ & Economics & Finance & Capital \\
\hline Purdue University & 9 & USA & E, SS, B & Finance & Investments & $\begin{array}{c}\text { Risk } \\
\text { Management }\end{array}$ \\
\hline Harvard Business School & 8 & USA & $\begin{array}{l}\text { BMA, DS, } \\
\text { CS }\end{array}$ & Finance & $\begin{array}{c}\text { Industrial } \\
\text { Management }\end{array}$ & Industry \\
\hline University College London & 8 & UK & E, BMA, ES & Finance & Costs & Investments \\
\hline
\end{tabular}

ES: Environmental Science; M: Medicine; ABS: Agricultural and Biological Sciences; BMA: Business, Management and Accounting; EEF: Economics, Econometrics and Finance; CS: Computer Science; E: Engineering; SS: Social Sciences; H: Health Professions; DS: Decision Sciences.

Moreover, Table 6 also shows the main keywords of the most productive research institutions in this topic. The most used keyword in the research developed by the 10 most productive financial technology institutions is 'Finance', where 7 institutions use it in first position, 1 in second, and 2 in third, thus highlighting the financial aspect of this topic. They are followed by risk assessment, decision-making and investments. Less important is a group of keywords that are related to different aspects of the research: technological (Technology, Information Technology, Biotechnology and Industry), economic-financial (Build Operate Transfers, Economics, Costs, Economic Aspect and Capital), administrative (Organization and Management, and Industrial Management), social (Developing Country, and Societies and Institutions) and commercial (Marketing).

The publications of the main institutions are linked to the thematic axes that analyse the financial and economic aspects of the research. 
Figure 6 shows the network of institutions based on the co-authorship analysis. The VOSviewer software tool associates them into three groups.

Cluster 1 (pink) groups $38.46 \%$ of the institutions, among which stand out the Business and Management Research Institute, University Of Bedfordshire (United Kingdom); Capgemini UK Ltd. (United Kingdom); Ceo, Commissioner of E-Governance, Government of Tamil Nadu (India); Department of Digitalization, Copenhagen Business School (Denmark); Department of Management Studies, Indian Institute of Technology, Delhi (India); Department of Marketing, Events and Tourism, University of Greenwich (United Kingdom); Department of Mathematics, Computational Foundry, Swansea University (United Kingdom); Department of Physics, College Of Science, Swansea University (United Kingdom); Economics Department, University of West of England (United Kingdom); and Emerging Markets Research Centre (EMaRC), School of Management, Swansea University (United Kingdom).

Cluster 2 (green) joins 38.46\%, among others, to Information and Communication Technology Section, Faculty of Technology, Policy and Management, Delft University of Technology (Netherlands); Information Systems Area, Indian Institute of Management Tiruchirappalli (India); Institute For Analytics and Data Science, University of Essex (United Kingdom); International Business, Marketing And Branding Research Centre, School of Management, University of Bradford, Bradford (United Kingdom); Manipal Global Education Services, Bangalore (India); Morgan Academy, School of Management, Swansea University (United Kingdom); Norwich Business School, University of East Anglia, Norwich, Norfolk (United Kingdom); Operations \& Information Management Department, Aston Business School (United Kingdom); Prin. L.N. Welingkar Institute of Management Development \& Research, Mumbai (India); and School of Business and Economics, Loughborough University (United Kingdom).

Finally, cluster 3 (violet) associates $23.08 \%$, among others, School of Education, Swansea University, Swansea, (United Kingdom); School of Management, Swansea University, (United Kingdom); School of Social and Political Sciences, University of Edinburgh, (United Kingdom); Swansea I-Lab (Innovation Lab), School of Management, Swansea University, (United Kingdom); Symbiosis Institute of Business Management, Pune \& Symbiosis International (Deemed) University, Pune (India); or Urban Scale Interventions, (United Kingdom).

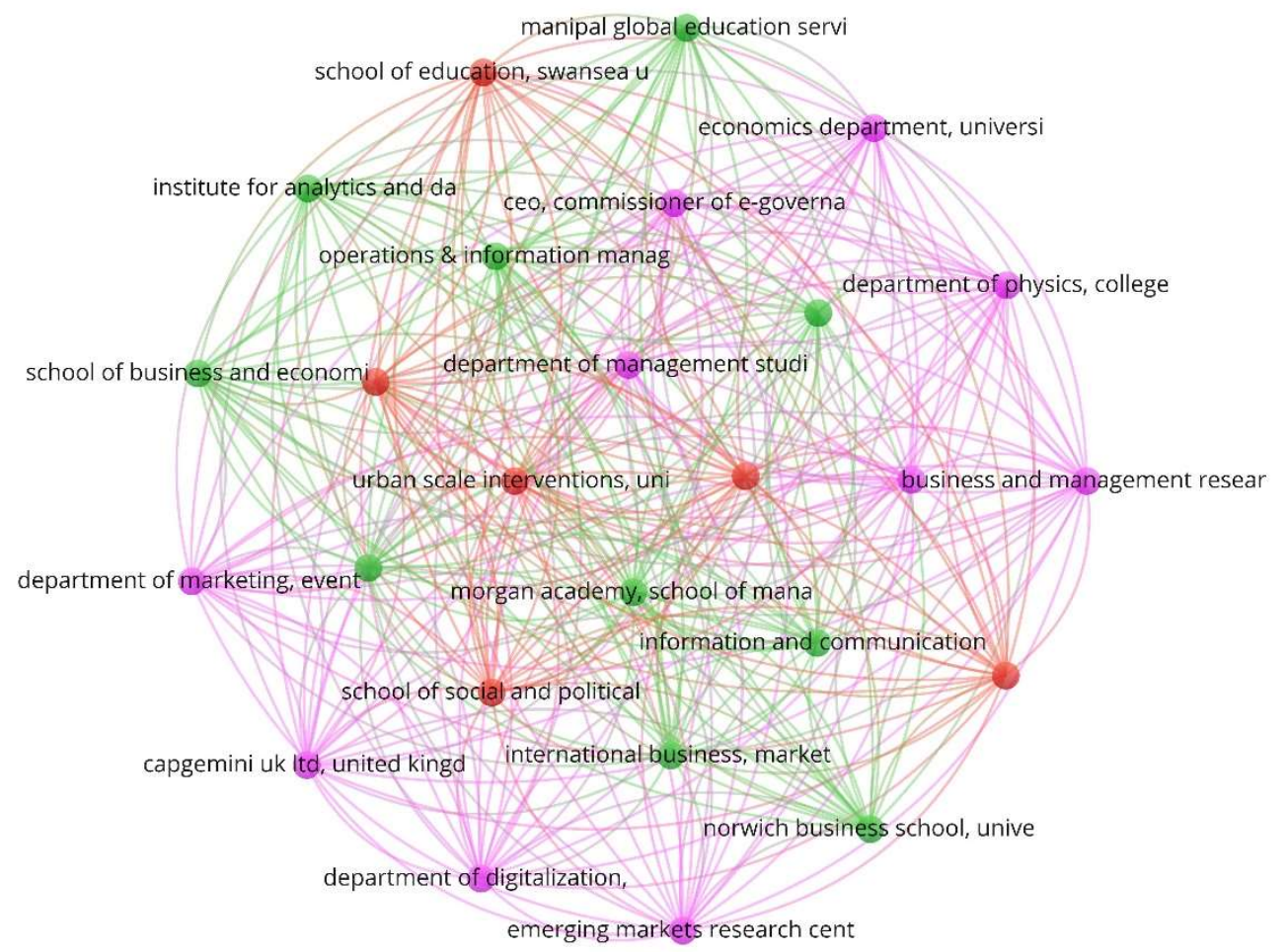

Figure 6. Network of research institutions based on co-authorship method (1975-2019). 
In this order, the United Kingdom has bet on the study of financial innovation, and transferring debate and research on the future of the international financial services sector from research centres and universities to society [139].

In this research topic, the 2012 articles were written in 108 different countries. Table 7 shows the top 10 countries in this field. The country with the most articles is the United States (560, 27.83\%), followed by the United Kingdom (216, 10.74\%). Then followed by the China $(175,8.70 \%)$, India $(79,3.93 \%)$, Germany $(71,3.53 \%)$ and Canada $(67,3.33 \%)$. Each of the remaining countries did not exceed $3 \%$ of the total articles.

Business, Management and Accounting is the thematic area that mostly associates articles associated with the most prolific countries (8 of 10) in financial technology research, during the period 1975-2019. China mainly classifies them in Engineering, and Russia in Economics, Econometrics and Finance.

Furthermore, Table 14 also presents the three main keywords to the most productive countries in this research topic. The most used keyword in the articles is 'Finance', used in the 10 countries first. The main keywords used by these 10 countries are associated in three different groups. In this way, they are associated with the technological aspects of the research topic (Information Technology, Technology and Technology Transfer); with management aspects (Financial Management, Information Management, Management, Organization and Management, Project Management, Risk Management and Decision Making); and with the financial aspects (Financial Management, Investments and Risk Management).

The publications of the main countries are linked to the thematic axes that analyse the financial, economic, innovation and investment aspects of research. In the same way that happens with the main research institutions, the United States and the United Kingdom are the countries that contribute the most to the development of financial technology research [140].

Table 14. Top 10 countries: main thematic area and keywords (1975-2019).

\begin{tabular}{|c|c|c|c|c|c|c|}
\hline Country & Article & $\%$ & $\begin{array}{l}\text { Thematic } \\
\text { Area }\end{array}$ & Keyword 1 & Keyword 2 & Keyword 3 \\
\hline USA & 560 & 27.83 & BMA & Finance & Information Technology & $\begin{array}{l}\text { Organization and } \\
\text { Management }\end{array}$ \\
\hline UK & 216 & 10.74 & BMA & Finance & Information Technology & Project Management \\
\hline China & 175 & 8.70 & E & Finance & Information Management & $\begin{array}{c}\text { Financial } \\
\text { Management }\end{array}$ \\
\hline India & 79 & 3.93 & BMA & Finance & Information Technology & $\begin{array}{l}\text { Developing } \\
\text { Countries }\end{array}$ \\
\hline Germany & 71 & 3.53 & BMA & Finance & Information Technology & Technology \\
\hline Canada & 67 & 3.33 & BMA & Finance & Technology & Decision Making \\
\hline Australia & 54 & 2.68 & $\mathrm{BMA}$ & Finance & Information Technology & Technology Transfer \\
\hline Netherlands & 44 & 2.19 & BMA & Finance & Technology & Risk Management \\
\hline Italy & 43 & 2.14 & BMA & Finance & Technology Transfer & Investments \\
\hline Russia & 42 & 2.09 & EEF & Finance & Management & Technology \\
\hline
\end{tabular}

\%: percentage of total articles published; BMA: Business, Management and Accounting; E: Engineering; EEF: Economics, Econometrics and Finance.

Figure 7 shows a collaboration map between the main countries based on the co-authorship analysis. Likewise, the different colours correspond to the different clusters of countries, while the diameter of the circle varies depending on the number of articles published by each country. The VOSviewer tool has grouped them into six components.

Cluster 1 (pink), the most numerous, includes $39.08 \%$ of the countries, and is headed by the United Kingdom. This is associated, among others, with Canada, France, Germany, Netherlands, Ireland, Finland, Sweden, South Korea, Spain, Belgium, Japan, Switzerland, Ghana, Turkey, Indonesia, Nigeria, Iran, Tanzania, Congo, Ethiopia, Tunisia, Pakistan, Sri Lanka, Zimbabwe, Oman, Cameroon, Gabon, Luxembourg, Jordan, Bangladesh, Barbados, British Isles or Brunei Darussalam. 
Cluster 2 (green), includes 31.03\% of the countries, is led by the United States and shares work with China, Australia, Taiwan, India, Hong Kong, Austria, Denmark, New Zealand, Kuwait, Singapore, Malaysia, Norway, Russia, Thailand, Ukraine, Saudi Arabia, Israel, Czech Republic, Fiji, Macau, Iceland, United Arab Emirates, Philippines, Bahrain, Iraq and Bulgaria.

Cluster 3 (network), includes $10.34 \%$ of the countries, is led by South Africa, and includes countries such as Kenya, Uganda, Poland, Lithuania, Slovenia, Croatia, Serbia and Montenegro.

Cluster 4 (yellow), includes $10.34 \%$ of the countries, is headed by Brazil, and includes Argentina, Costa Rica, Mexico, Chile, Colombia, Uruguay, Bolivia and Paraguay.

Cluster 5 (violet), includes $5.75 \%$ of the countries, is led by Italy, includes Mozambique, Hungary, Albania and Mongolia.

Finally, Cluster 6 (blue), includes 3.45\% of the countries, is headed by Greece, and cooperates with Portugal and Cyprus.

At a global level, led by the United States, the United Kingdom and China, research is focusing on different areas, such as technological risk, cyber risk and the management of the change of financial technologies in the individual and in society [141,142]. Furthermore, the potential of AI for financial services will be analysed, along with the ethical challenges, the skills gap between people and the risks associated with the changing dynamics of the market and the technology and financial industry [143].

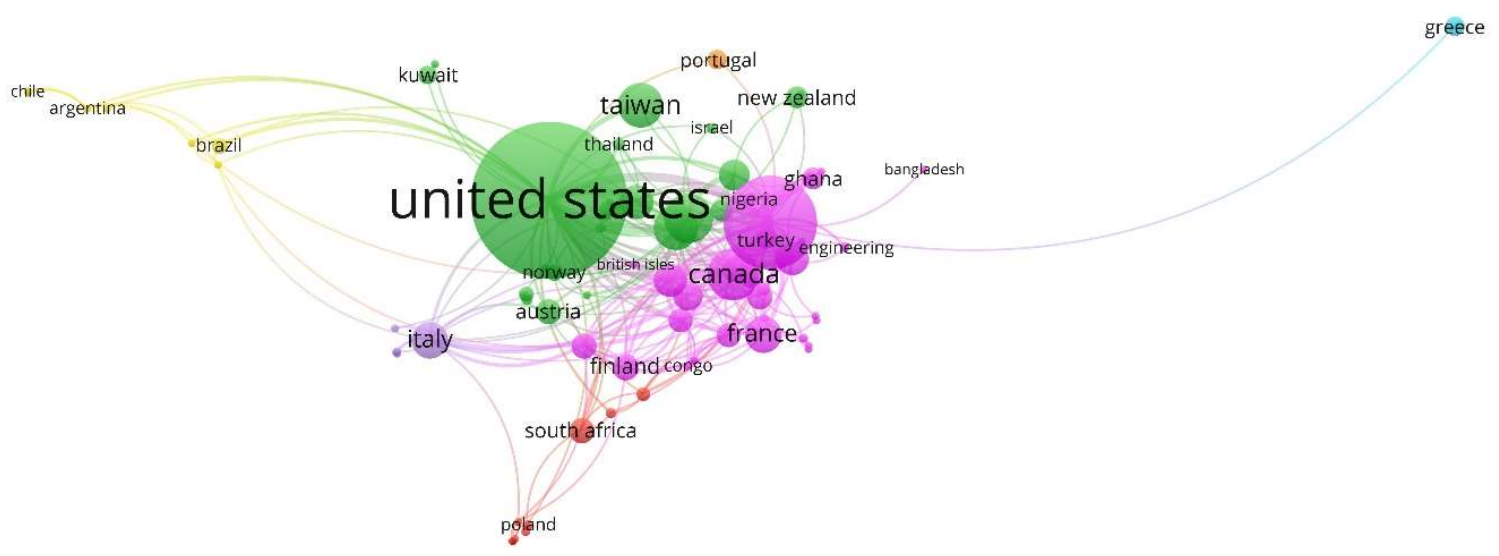

Figure 7. Network of countries based on co-authorship method (1975-2019).

\subsection{Evolution of Keywords}

Figure 8 shows the evolution and maturity of each keyword community, since it differentiates the period in which they have been studied and associated with the documents examined. In this way, it is verified that there has been an evolution in terminology in the research of financial technologies, which can, in turn, be divided into four sub-periods: 1975-2004, 2005-2009, 2010-2014 and 2015-2018.

In the first period (1975-2004) the keywords that were shaping the study theme were incorporated. These have been the pioneers and have allowed the establishment of a field of research. Among the main terms, the following are highlighted by total link strength: planning, research, cost control, information processing, technological forecasting, risks, public sector, geographic distribution, program evaluation, evaluation studies, demography, purchasing, process control, socioeconomic factors, environmental planning, organisations, technology, high-cost, developed country, statistical analysis, government agencies, information theory, operating costs, management tool, monitoring, data communication systems, organisational culture, teamwork, knowledge engineering, fee, personal computers, metropolitan area networks, resource development, economic performance, finance control, finance management, financial analyses, financial assistance, financial bottom line indexes, financial deregulation, financial flows, financial holding, financial investors, financial optimisation, financial organisation, financial performance, financial planning, financial plan, financial ratio, financial report and financial resource. 
This first period defined emerging financial services that use information technology applicable to the final phase of consumption of a financial service [144].

In a second period (2005-09) new terms were incorporated into the research theme, among which the following stand out: agent-based model (ABM), agent-based systems, agglomeration economies, alternative approaches, alternative trading systems, business angel, business communication, business environment, business functions, business goals, business intelligence (BI), business knowledge, business leaders, business planning, business plans, business process management system, business process reengineering, business process reengineering (BPR), business processing, business productivity, business skills, business strategy, business system domains, business transformations, business value of it, capital and operating costs, capital costs, capital funds, capital market-asset, capitalist organisations, commercial banks, computer supported cooperative work (CSCW), co-payments, cost controls, cost functions, cost increase, cost information, cost minimization analysis, cost optimal control, cost-analysis, credit cards, credit evaluation management, credit supply, data flow analysis, data flow diagram, data flow diagrams, data flow graphs, data gathering, data import, data limitations, economic competitiveness, economic developments, economic efficiency, economic growth rates, economic history, economic instrument, economic level, finance managements, finance structuring, financial analyses, financial digitisation, financial engineerings, financial holding, financial holding companies, financial index, financial indices, financial investors, financial organizations, financial performances, financial plans, financial ratio, financial reports, industrial innovations, industrial installations, industrial logging, industrial property, industrial sectors, information technology outsourcing, information technology procurement methods, information technology restructuring, international finance, international financial management, international investments, international organization, international relations, inventory systems, investment allocation, investment capital, investment decision and investment planning.

In the second period, the new disruptions in the financial sector and the business models that Fintech's bring about are shaped [31,40].

Likewise, it is observed that there has been an evolution in the key terms related to the research topic during a third period 2010-2014, among which the following stand out: manager, artificial intelligence, public-private partnership, environmental regulations, earnings, life cycle assessment, computer security, demand-side management, financial risks, surgery, supply chain, society, business development, microfinance, wellbeing, satisfaction, e-learning, enterprise resource management, corporate strategy, financial viability, accountability, commercial activity, empirical research, teaching and learning, teaching approaches, teaching experience, financial and nonfinancial indicators, financial appraisal, financial constraints, financial decisions, financial feasibility, financial information service system, financial instruments, financial loss, financial management system, financial modelling, financial objectives, financial reporting, financial risk analysis, financial risks, financial service innovation, financial supply chain management, financial viability, financialisation, financing constraints, financing services, bivariate $\operatorname{ar}(\mathrm{p})$ model, bivariate time series, black swan, business continuity, business continuity planning, business curriculum, business decisions, business development, business flow, business formation and business marketing.

This third period includes the magnitude of the change that the financial sector is undergoing and the generational change in financial services [145].

Finally, in fourth the period (2015-18), which coincides with the largest exponential increase in the publication of articles on financial technologies, a set of terms have been linked to this research topic, among which stand out for total link strength: Fintech, blockchain, electronic money, bitcoin, cryptocurrency, innovation, big data, artificial intelligence, financial services, financial inclusion, banking, crowdfunding, sales, electronic commerce, regtech, privacy, mobile payment, machine learning, china, data privacy, authentication, cryptography, security, global system for mobile communications, peer-to-peer lending, smart contract, financial regulation, P2P lending, digital economy, financial market, digitisation, cyber security, technology acceptance model, 
peer to peer networks, learning systems, technology adoption, financial transactions, economic development, business modelling, risk assessment, mobile banking, mobile phone, sustainability, information asymmetry, sustainable development, platforms, Ethereum, mobile telecommunication systems, network security, crowdsourcing, regulatory technology, mobile banking, economic analysis, technological innovation, financial innovation, United States, Internet of Things, e-commerce, peer to peer, purchasing, data analytics, business model, least squares method and currency.

In this fourth period, the fintech phenomenon formally implies a paradigm shift that has revolutionised the financial sector, and the challenges it poses are analysed [32,146].

The different periods and the large number of keywords associated with international research in financial technologies allow us to understand the variety of study axes in research activity. Therefore, this Figure 8 allows us to understand the importance of the key terms based on the time in which they have appeared, that is, the pioneers have had a greater influence and have been a reference for those that have emerged later.
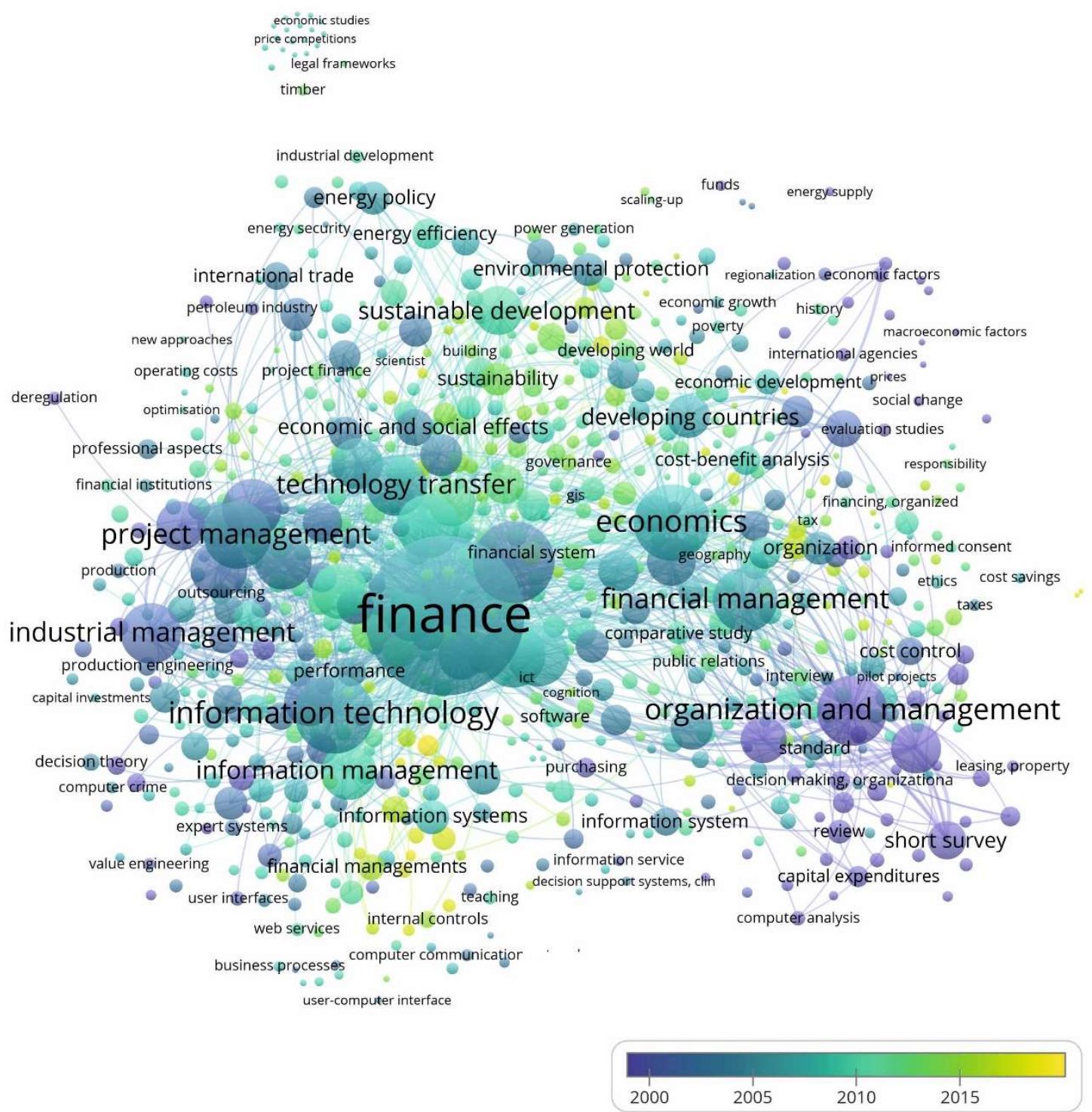

Figure 8. Network of keywords based on co-occurrence method (Evolution, 1975-2019). 


\subsection{Future Research Lines}

Globally, research continues to advance, so since 2019 other concepts and strategies are being incorporated, giving rise to new research lines. Into the bargain, a set of terms can be associated with the different future thematic axes that relate to the different aspects of Fintech:

- Banking: bank misconduct, bank regulations, bank run, banking industry, banking sector, commercial bank, consumer loans, operating efficiency, savings, conventional commercial banks, corporate banking, credit constraint, credit provision, customer records, defined contribution pension plan, P2P/marketplace lending, payment services directive 2 (PSD 2), peer to peer lending, personalised recommendation, systemically important banks and access to accountaer.

- Commercial: market price, market stability, marketing strategy, public relations, know your customer and life cycle.

- Development of territories, religion, migratory movements and refugee flows: Africa, Bahrain, Chinese Economy, Chinese inclusive finance, Greece, Hong Kong, Islamic finances, Islamic financial services marketing, Kenya, Kingdom of Bahrain, refugees, Sub-Sahara Africa and Zimbabwe.

- Economic and business: growth, industrial economics, inequality, labour transfer, policy risk, poverty reduction, social change, social restrictions, business cycle, capital bubble, capitalism, development history, development process, economic cycle, economic welfare, entrepreneur, future of real estate, industry revolution 4.0, migration, service industry, small and medium enterprise, small and medium enter-prises, small business finance, social restrictions and start-up.

- Financial: financial access, financial fragility, financial frontier technology, financial resilience, financial risk early warning, financial technology, financial wellbeing, fintech education, fintech events, fintech firms, fintech opportunities, fintech threats, investors' sentiment, invest-tech, corporate finance, digital financial services, electronic payment infrastructure, household finance, inclusive finance, interest rate liberalization, $\mathrm{P} 2 \mathrm{P} /$ marketplace lending, payment services directive 2 (PSD 2), peer to peer lending, return on equity, sentiment analysis, shanghai stock exchanges, stock markets, decentralised finance, early-stage finance, initial coin offering (ICO), logistics finance, monetary system, risk and performance, sentiment analysis, SME finance, start-up funding, supply chain efficiency, supply chain financials and supply chain financing.

- Legal: consumers and legal protection, robo advisors, security and privacy issues, controversy, digital regulatory reporting, general data protection regulation (GDPR), government role, inclusive development, institutional change, institutional reform, payment services directive 2 (PSD 2), institutionalisation, labour transfer, ontology, regulatory body and model driven regulation.

- Management: asset management company, automated investment management, management decisions, management of finance, human resource management, relationship management, trust management, business management and learning managements.

- $\quad$ Research Methods: bibliometric, bibliometrics, co-citation analysis, co-citation networks, co-word analysis, cluster, clustering algorithms, heterogeneous data, baseline studies, classification framework, comprehensive analysis, comprehensive monitoring, engineering research, genetic algorithms, genetic learning, goal programming, goal-based investing, higher education, in-depth analysis, industrial research, k-mean clustering algorithm, k-means clustering, knowledge gaps, numerical model, object-oriented methodology, quantitative method, reliability analysis, reliability and validity, reporting framework, research frames, research institutions, research methodologies, research questions, review, unified theory of acceptance and use of technology (UTAUT), state-of-the-art technology, statistical tests, stochastic frontier, system equations and systematic review.

- Sustainability: ecology, sustainable business model, sustainable development goals (SDGs), sustainable investment and sustainable management.

- Technologies: Internet big data, bitcoin merchants, bitcoin mining pool, bitcoin network, bitcoin nodes, big tech, blockchain agent, blockchain regulation, consortium blockchain, computational 
constraints, computational methods, computer architecture, computing architecture, computing power, cryptoassets, digital conglomerates, digital economy era, digital farming, digital identity, digital payments, digital wealth management, electronic payment infrastructure, fog computing, mobile cloud computing, P2P/marketplace lending, payment services directive 2 (PSD 2), personalised recommendation, smart technologies, visual analytics systems, visual reasoning, web search behaviour, arts computing, characteristics of Fintech, disruptive innovations, internet technology and supporting technology.

The analysis of the terms most recently associated with financial technology research has made it possible to differentiate ten different future thematic axes of this research. In the lines of banking, legal, technologies and financial aspects, the analysis of the implementation of Directive (EU) 2015/2366 related to Payment services (PSD 2) and the measures of its transposition by the Member States of the EU stands out to national legislation. This regulation is mainly related to financial institution, electronic money payment, intra-EU payment, approximation of laws, electronic banking, single market, service, financial legislation and financial services [147].

Other studies should develop an analysis of the start-up's initial funding sources, which will be adapted to the type of business, such as banks, grants, venture capitalists, friends and family, angel investors, bootstrapping and crowdfunding (equity crowdfunding, rewards- based crowdfunding, or debt-based crowdfunding) [148].

In relation to research methodologies, various studies should review the status of the question and the progress of research over time, in order to provide valuable results to companies, regulatory institutions, decision-makers, investors, researchers and academics [53,74].

In addition, the research should address the transition from financial technology to sustainable finance related to the SDGs. Sustainable finance must guide economic growth towards more humane and balanced development. In this sense, the Fintech sector will be decisive. Digital platforms need more agile infrastructures, in order to make the range of financial services available to less developed populations. Sustainability of finance means that developing countries can expand access to financial services, reduce pollution, improve public health and stimulate the use of clean energy. At the same time, the more developed countries can obtain benefits with a more complete market, linked to the real economy and to the transition towards renewable energy [149].

\section{Conclusions}

The objective of this study was to analyse the evolution of scientific production and research trends at a global level, over the last 45 years, on financial technology. To this end, a bibliometric analysis of a sample of 2012 articles obtained from the Scopus database has been developed. Fundamentally, the evolution of the number of documents, the thematic areas where they are classified, the journals where they are published, the authors, the research institutions and the most productive countries have been identified, in addition to the current and future research lines through the analysis of keyword communities.

The volume of scientific articles has increased remarkably in the past decade (2010-19), where 905 documents have been published, which represents $44.98 \%$ of the total contributions on the subject of financial technology, which confirms the relevance and impact of this research topic.

On the other hand, this study has also identified the most influential areas of knowledge where publications are classified: Business, Management and Accounting; Engineering; Social Sciences; and Computer Science, which shows the interest of the subject of study by a wide sector of the international scientific community. In a similar way, the main journals classify their articles, mainly, in the thematic area Business, Management and Accounting, and to a lesser extent, Engineering and Environmental Science.

The main thematic axes developed in the research of financial technologies refer to the study of different aspects, such as: (i) financial from technological, management, customer satisfaction and financial data processing approaches; (ii) economic and statistical and management processes that 
allow an organization to obtain economic and operational improvements; (iii) the impact of technology transfer and its relationship with a more sustainable society; (iv) investments and actors involved; (v) research in financial technological innovation; (vi) the impact of policies and processes on society and institutions; and (vii) modernization, productivity, industrial development and standardisation.

The publications of the main authors, research institution and countries are linked to the thematic axes that analyse the financial, economic, innovation, commercial and investment aspects of this research topic. Moreover, the United States and the United Kingdom are the countries that contribute the most to the development of financial technology research.

Likewise, at an international level, research continues to advance, giving rise to future research lines, which must develop analyses of different aspects of financial technologies, such as: financial, banking, trade in financial services, development of territories, religion, economic movements, commercial, legal, management, research methods, sustainability and technological.

This study has a set of limitations, which have conditioned the results obtained, and these can be considered as a basis for future researches. These include the Scopus database chosen to apply the methodology; the keywords selected to extract the sample of articles; the time horizon of the study; the applied bibliometric method; or the variables analysed. Another significant limitation of this study is the exclusive analysis of the key terms in the title, abstract and keywords of the sample documents, so that the study could be expanded using advanced algorithms, such as data mining algorithms for a greater focus and results.

Thereupon, this research study supposes an analysis of the scientific production and of the actors that stimulate the investigation of financial technology, during the period 1975-2019, as well as the identification of the lines of investigation and their evolution and transformation. At the same time, innovation in this research field has been identified based on the morphology of the groups of authors, institutions, countries and keywords, and the intensity of the relationships that develop in them. In this way, the findings obtained in this research are a complement to the knowledge of financial technologies and allow to establish the relationship between science and technique, and to inform the decision-making process.

Finally, it has been observed that international research on financial technology presents an upward trend, derived mainly from the number of articles such as current and future research lines, which indicates the growing interest in the academic and scientific community. In other words, it is observed that the scientific activity on financial technologies is developed in a favourable environment, with a general interest in the dissemination of the results of the publications, allowing technical progress.

Author Contributions: Conceptualisation, methodology, software, formal analysis, resources, data curation and writing - original draft preparation, E.A.-S. and M.-D.G.-Z.; investigation, validation, writing — review and editing, visualisation, supervision, project administration, E.A.-S., M.-D.G.-Z., E.L.-M. and E.V.-C.; funding acquisition, E.L.-M. and E.V.-C. All authors have read and agreed to the published version of the manuscript.

Funding: This research received no external funding.

Conflicts of Interest: The authors declare no conflict of interest.

\section{References}

1. Müller, J.; Kerényi, Á. The Need for Trust and Ethics in the Digital Age-Sunshine and Shadows in the FinTech World. Financ. Econ. Rev. 2019, 18, 5-34. [CrossRef]

2. Breidbach, C.F.; Keating, B.W.; Lim, C. Fintech: Research directions to explore the digital transformation of financial service systems. J. Serv. Theory Pract. 2019, 30, 79-102. [CrossRef]

3. Basole, R.C.; Patel, S.S. Transformation Through Unbundling: Visualizing the Global FinTech Ecosystem. Serv. Sci. 2018, 10, 379-396. [CrossRef]

4. O'Halloran, S.; Nowaczyk, N. An Artificial Intelligence Approach to Regulating Systemic Risk. Front. Artif. Intell. 2019, 2, 1-14. [CrossRef]

5. Wonglimpiyarat, J. Analysis of FinTech in the banking industry. Int. J. Bus. Innov. Res. 2019, 19, 125. [CrossRef] 
6. Iman, N. Assessing the dynamics of fintech in Indonesia. Invest. Manag. Financ. Innov. 2018, 15, $296-303$. [CrossRef]

7. Chen, M.A.; Wu, Q.; Yang, B. How Valuable Is FinTech Innovation? Rev. Financ. Stud. 2019, 32, $2062-2106$. [CrossRef]

8. Bukharin, H.O. Fintech: Trends of development and regulatory policy. Herald of Zaporizhzhia National University. Jurisprudence 2019. [CrossRef]

9. Song, K.-S. Investigation of Business Model on Fintech Payment System. E-Bus. Stud. 2015, 16, 65-94. [CrossRef]

10. Tian, X.; Han, R.; Wang, L.; Lu, G.; Zhan, J. Latency critical big data computing in finance. J. Financ. Data Sci. 2015, 1, 33-41. [CrossRef]

11. Wonglimpiyarat, J. What is it about strategic implications of using financial models in the process of technology management? J. High Technol. Manag. Res. 2019, 30, 82-90. [CrossRef]

12. Li, Y.; Liu, Y.; Xie, F. Technology directors and firm innovation. J. Multinatl. Financ. Manag. 2019, 50, 76-88. [CrossRef]

13. Zavolokina, L.; Dolata, M.; Schwabe, G. The FinTech phenomenon: Antecedents of financial innovation perceived by the popular press. Financ. Innov. 2016, 2. [CrossRef]

14. Chang, H.; Liang, W.; Wang, Y. Do institutional investors still encourage patent-based innovation after the tech bubble period? J. Empir. Financ. 2019, 51, 149-164. [CrossRef]

15. Hendrikse, R. Can selfies spark the identity (r)evolution in financial services? Biom. Technol. Today 2019, 2019, 5-7. [CrossRef]

16. Mention, A.-L. The Future of Fintech. Res. -Technol. Manag. 2019, 62, 59-63. [CrossRef]

17. Yacoub, G. Collaborative Innovation and Appropriability in Start-ups: Evidence from the FinTech Sector. Acad. Manag. Proc. 2017, 2017, 13674. [CrossRef]

18. Gardiner, A.E. Finance. Int. J. Dairy Technol. 1978, 31, 122-124. [CrossRef]

19. Sellers, W.O. Technology and the future of the financial services industry. Technol. Soc. 1985, 7, 1-9. [CrossRef]

20. Wang, J.-Y. Technology transfer in international business. Int. Rev. Econ. Financ. 1994, 3, 355-357. [CrossRef]

21. Simon, H.A. Artificial intelligence: An empirical science. Artif. Intell. 1995, 77, 95-127. [CrossRef]

22. Sahut, J.-M. The Adoption and Diffusion of Electronic Wallets, World Academy of Science, Engineering and Technology, Open Science Index 17. Int. J. Econ. Manag. Eng. 2008, 2, 525-528. [CrossRef]

23. Lescourret, L. Cold Case File? Inventory Risk and Information Sharing during the pre-1997 NASDAQ. Eur. Financ. Manag. 2017, 23, 761-806. [CrossRef]

24. Armstrong, L. Bank of America secures the internet. Netw. Secur. 1994, 1994, 4-5. [CrossRef]

25. Rella, L. Blockchain Technologies and Remittances: From Financial Inclusion to Correspondent Banking. Front. Blockchain 2019, 2, 14. [CrossRef]

26. Descy, D.E. All aboard the internet google-eyed over google! TechTrends 2004, 48, 5-7. [CrossRef]

27. Schackmann-Fallis, K.-P. Do We Need More Financial Integration? Appl. Econ. Quaterly 2014, 60, $115-121$. [CrossRef]

28. Guo, J.; Bouwman, H. An analytical framework for an m-payment ecosystem: A merchants' perspective. Telecommun. Policy 2016, 40, 147-167. [CrossRef]

29. Dospinescu, O.; Anastasiei, B.; Dospinescu, N. Key Factors Determining the Expected Benefit of Customers When Using Bank Cards: An Analysis on Millennials and Generation Z in Romania. Symmetry 2019, 11, 1449. [CrossRef]

30. European Commission. High-Level Conference: A Global Approach to Sustainable Finance. Available online: https://ec.europa.eu/info/events/finance-190321-sustainable-finance_en (accessed on 7 May 2020).

31. An, J.; Rau, R. Finance, technology and disruption. Eur. J. Financ. 2019. [CrossRef]

32. Kerényi, Á.; Müller, J. Brave New Digital World?-Financial Technology and the Power of Information. Financ. Econ. Rev. 2019, 18, 5-32. [CrossRef]

33. Schich, S. Do Fintech and Cryptocurrency Initiatives Make Banks Less Special? Bus. Econ. Res. 2019, 9, 89. [CrossRef]

34. Abouayoub, N. Why Finance Needs Tech and AI. ITNOW 2018, 60, 10-11. [CrossRef]

35. Anagnostopoulos, I. Fintech and regtech: Impact on regulators and banks. J. Econ. Bus. 2018, 100, 7-25. [CrossRef] 
36. Leong, K. FinTech (Financial Technology): What is It and How to Use Technologies to Create Business Value in Fintech Way? Int. J. Innov. Manag. Technol. 2018, 9, 74-78. [CrossRef]

37. Treleaven, P.; Gendal Brown, R.; Yang, D. Blockchain Technology in Finance. Computer 2017, 50, 14-17. [CrossRef]

38. Kim, Y.; Cin, B.C.; Cho, K.; Yi, J. Introduction: Technology, Finance, and Trade in Emerging Markets. Emerg. Mark. Financ. Trade 2015, 51, 945-946. [CrossRef]

39. Gaftea, V. Socio-economic Major Risks Related to the Information Technology. Procedia Econ. Financ. 2014, 8, 336-345. [CrossRef]

40. Ethier, W.J. Globalization, globalisation: Trade, technology, and wages. Int. Rev. Econ. Financ. 2005, 14, 237-258. [CrossRef]

41. Kritzman, M. Technology and the Infrastructure of Financial Flows. Int. Financ. 2003, 6, 455-466. [CrossRef]

42. Persons, O.S. The relationship between research \& development expenditure and executive compensation in high-technology industries. Manag. Financ. 1999, 25, 55-67. [CrossRef]

43. De la Mothe, J.; Paquet, G. Finance and the technology-trade nexus. Technol. Soc. 1998, 20, 441-468. [CrossRef]

44. Holsapple, C.W.; Tam, K.Y.; Whinston, A.B. Adapting Expert System Technology to Financial Management. Financ. Manag. 1998, 17, 12. [CrossRef]

45. Williamson, M. Information Technology and Financial Institutions. Manag. Financ. 1984, 10, 6-10. [CrossRef]

46. Lee, S. Geography of cross-border portfolio investments and ICT diffusion. Int. Rev. Econ. Financ. 2016, 45, 540-552. [CrossRef]

47. Dimelis, S.P.; Papaioannou, S.K. Technical Efficiency and the Role of ICT: A Comparison of Developed and Developing Countries. Emerg. Mark. Financ. Trade 2011, 47 (Suppl. S3), 40-53. [CrossRef]

48. Gulbe, M. Quantitative Characteristics of Information Society and ICT Industry in Latvia. Procedia Econ. Financ. 2015, 26, 682-687. [CrossRef]

49. Lee, S.-H.; Lee, D.-W. FinTech-Conversions of Finance Industry based on ICT. J. Korea Converg. Soc. 2015, 6, 97-102. [CrossRef]

50. Shakina, E.; Angerer, M. Coordination and communication during bank runs. J. Behav. Exp. Financ. 2018, 20, 115-130. [CrossRef]

51. Kwak, J.K. Information Technology Implementation and Operational Efficiency. Manag. Sci. Financ. Eng. 2013, 19, 13-18. [CrossRef]

52. Zhou, B. Enterprises' Treasury Management Strategy in Post Financial Crisis Era. Qual. Technol. Quant. Manag. 2014, 11, 217-222. [CrossRef]

53. Zhang, D.; Zhang, Z.; Managi, S. A bibliometric analysis on green finance: Current status, development, and future directions. Financ. Res. Lett. 2019, 29, 425-430. [CrossRef]

54. Vázquez-Cano, E.; Gómez-Galán, J.; Infante-Moro, A.; López-Meneses, E. Incidence of a Non-Sustainability Use of Technology on Students' Reading Performance in Pisa. Sustainability 2020, 12, 749. [CrossRef]

55. Maeng, S.-S.; Lee, H.-W. FinTech Development and Financial Consumer Protection Policy. Bus. Law Rev. 2017, 31, 331-365. [CrossRef]

56. Raluca, D.A.; Alecsandru, S.V. Patterns of Foreign Direct Investment in Romania: Low Tech Investments versus High Tech Investments. Procedia Econ. Financ. 2014, 10, 275-285. [CrossRef]

57. Hardjono, T.; Lipton, A.; Pentland, A. Toward a Public-Key Management Framework for Virtual Assets and Virtual Asset Service Providers. J. FinTech 2020, 2050001. [CrossRef]

58. Nikkel, B. Fintech forensics: Criminal investigation and digital evidence in financial technologies. Forensic Sci. Int. Digit. Investig. 2020, 200908. [CrossRef]

59. Shkodina, I.V.; Timoshenkov, I.V.; Nashchekina, O.N. The impact of financial technology on the transformation of the financial system. Financial and Credit Activity: Probl. Theory Pract. 2018, 1, 417-424. [CrossRef]

60. Winnefeld, C.H.; Permantier, A. FinTech-The digital (R)Evolution in the German Banking Sector? Bus. Manag. Res. 2017, 6, 65. [CrossRef]

61. Khanizad, R.; Montazer, G. Participation against competition in banking markets based on cooperative game theory. J. Financ. Data Sci. 2018, 4, 16-28. [CrossRef]

62. Cendana, D.I. Designing a Digital Payment Framework for HEI's Using Smart ID. Int. J. Comput. Theory Eng. 2020, 12, 1-7. [CrossRef]

63. Lleo, S. Gods and Robots: Myths, Machines, and Ancient Dreams of Technology. Quant. Financ. 2019, 19, 545-546. [CrossRef] 
64. Sandu, S.; Ciocanel, B. Impact of R\&D and Innovation on High-tech Export. Procedia Econ. Financ. 2014, 15, 80-90. [CrossRef]

65. Wonglimpiyarat, J. Dynamics of Crowd Funding and FinTech Challenges. Int. J. Bus. Innov. Res. $2020,1,1$. [CrossRef]

66. Zhang, P.; Shi, X.; Khan, S.U. QuantCloud: Enabling Big Data Complex Event Processing for Quantitative Finance Through a Data-Driven Execution. IEEE Trans. Big Data 2019, 5, 564-575. [CrossRef]

67. Aldakhil, A.M. Effective Financial Management of Supply Chain through the Use of Emerging Technology. Int. J. Financ. Res. 2015, 7. [CrossRef]

68. Jung, L.-S. The Relationship between Attitude and Satisfaction for Improving Continue User Intention in Fintech. Int. J. It Bus. Strategy Manag. 2016, 2, 29-34. [CrossRef]

69. Hinson, R.; Lensink, R.; Mueller, A. Transforming agribusiness in developing countries: SDGs and the role of FinTech. Curr. Opin. Environ. Sustain. 2019, 41,1-9. [CrossRef]

70. Van Eecke, P.; Haie, A. Practitioner's Corner · Blockchain and the GDPR: The EU Blockchain Observatory Report. Eur. Data Prot. Law Rev. 2018, 4, 531-534. [CrossRef]

71. Cahill, D.; Baur, D.G.; Liu, Z.; Yang, J.W. I am a blockchain too: How does the market respond to companies' interest in blockchain? J. Bank. Financ. 2020, 113, 105740. [CrossRef]

72. Guégan, D.; Henot, C. A probative value for authentication use case blockchain. Digit. Financ. 2019, 1, 91-115. [CrossRef]

73. O'Neill, M.; Brabazon, A. Business analytics capability, organisational value and competitive advantage. J. Bus. Anal. 2019, 2, 160-173. [CrossRef]

74. Abad-Segura, E.; González-Zamar, M.-D. Global Research Trends in Financial Transactions. Mathematics 2020, 8, 614. [CrossRef]

75. Iman, N. Is mobile payment still relevant in the fintech era? Electron. Commer. Res. Appl. 2018, 30, 72-82. [CrossRef]

76. Hasan, M.M.; Popp, J.; Oláh, J. Current landscape and influence of big data on finance. J. Big Data 2020, 7. [CrossRef]

77. Cockcroft, S.; Russell, M. Big Data Opportunities for Accounting and Finance Practice and Research. Aust. Account. Rev. 2018, 28, 323-333. [CrossRef]

78. Logica, B.; Magdalena, R. Using Big Data in the Academic Environment. Procedia Econ. Financ. 2015, 33, 277-286. [CrossRef]

79. Aydiner, A.S.; Tatoglu, E.; Bayraktar, E.; Zaim, S.; Delen, D. Business analytics and firm performance: The mediating role of business process performance. J. Bus. Res. 2019, 96, 228-237. [CrossRef]

80. Kutelev, P.V. Business process re-engineering based on artificial intelligence management. Financ. Credit 2019, 25, 2889-2902. [CrossRef]

81. Quintana, D.; Isasi, P. Soft computing in finance and economics. AI Commun. 2014, 27, 171-172. [CrossRef]

82. Lagoze, C. Big Data, data integrity, and the fracturing of the control zone. Big Data Soc. 2014, 1, 205395171455828. [CrossRef]

83. Boehm, M.; Kumar, A.; Yang, J. Data Management in Machine Learning Systems. Synth. Lect. Data Manag. 2019, 14, 1-173. [CrossRef]

84. Li, Y.; Rafiei, D. Natural Language Data Management and Interfaces. Synth. Lect. Data Manag. 2018, 10, 1-156. [CrossRef]

85. Tiwari, I.; Goyal, A.; Joshi, A. Minning of Bitcoin Technology. Int. J. Electr. Electron. Comput. 2020, 5, $10-13$. [CrossRef]

86. Sokolov, V. Discussion of “Deep learning for finance: Deep portfolios". Appl. Stoch. Models Bus. Ind. 2017, 33, 16-18. [CrossRef]

87. Gregory, R.P. Financial openness and entrepreneurship. Res. Int. Bus. Financ. 2019, 48, 48-58. [CrossRef]

88. Yin, H. Bank globalization and financial stability: International evidence. Res. Int. Bus. Financ. 2019, 49, 207-224. [CrossRef]

89. Acar, O.; Çıtak, Y.E. Fintech Integration Process Suggestion for Banks. Procedia Comput. Sci. 2019, 158, 971-978. [CrossRef]

90. Allhoff, F.; Henschke, A. The Internet of Things: Foundational ethical issues. Internet Things 2018, 1, 55-66. [CrossRef] 
91. Samie, F.; Bauer, L.; Henkel, J. From Cloud Down to Things: An Overview of Machine Learning in Internet of Things. IEEE Internet Things J. 2019, 6, 4921-4934. [CrossRef]

92. Mbarek, B.; Ge, M.; Pitner, T. An Efficient Mutual Authentication Scheme for Internet of Things. Internet Things 2020, 9, 100160. [CrossRef]

93. Garfield, E. Derek Price and the Practical World of Scientometrics. Sci. Technol. Hum. Values 1988, 13, 349-350. [CrossRef]

94. Bhattacharya, S. Eugene Garfield: Brief reflections. Scientometrics 2017, 114, 401-407. [CrossRef]

95. Rousseau, R.; Hu, X. Under-cited influential work by Eugene Garfield. Scientometrics 2017, 114, 651-657. [CrossRef]

96. Bornmann, L.; Mutz, R. Growth rates of modern science: A bibliometric analysis based on the number of publications and cited references. J. Assoc. Inf. Sci. Technol. 2015, 66, 2215-2222. [CrossRef]

97. Nicolaisen, J.; Frandsen, T.F. Bibliometric evolution: Is the journal of the association for information science and technology transforming into a specialty Journal? J. Assoc. Inf. Sci. Technol. 2014, 66, 1082-1085. [CrossRef]

98. Chen, J.; Yang, L. A Bibliometric Review of Volatility Spillovers in Financial Markets: Knowledge Bases and Research Fronts. Emerg. Mark. Financ. Trade 2019. [CrossRef]

99. Sitenko, D.; Yessengeldin, B. The estimation of efficiency of the university innovation activity: Systems of indicators and bibliometric approach. J. Econ. Res. Bus. Adm. 2019, 129, 14-24. [CrossRef]

100. Belmonte-Ureña, L.J.; Garrido-Cardenas, J.A.; Camacho-Ferre, F. Analysis of World Research on Grafting in Horticultural Plants. HortScience 2020, 55, 112-120. [CrossRef]

101. Liu, W. Accuracy of funding information in Scopus: A comparative case study. Scientometrics 2020, 1-9. [CrossRef]

102. Brzezinski, M. Power laws in citation distributions: Evidence from Scopus. Scientometrics 2015, 103, $213-228$. [CrossRef] [PubMed]

103. Liberati, A. The PRISMA Statement for Reporting Systematic Reviews and Meta-Analyses of Studies That Evaluate Health Care Interventions: Explanation and Elaboration. Ann. Intern. Med. 2009, 151. [CrossRef]

104. Abad-Segura, E.; González-Zamar, M.D. Effects of Financial Education and Financial Literacy on Creative Entrepreneurship: A Worldwide Research. Educ. Sci. 2019, 9, 238. [CrossRef]

105. Behrens, H.; Luksch, P. Mathematics 1868-2008: A bibliometric analysis. Scientometrics 2010, 86, 179-194. [CrossRef]

106. Abad-Segura, E.; González-Zamar, M.-D.; de la Rosa, A.L.; Cevallos, M.B.M. Sustainability of Educational Technologies: An Approach to Augmented Reality Research. Sustainability 2020, 12, 4091. [CrossRef]

107. Norris, M.; Oppenheim, C. The h-index: A broad review of a new bibliometric indicator. J. Doc. 2010, 66, 681-705. [CrossRef]

108. Gómez-Núñez, A.J.; Vargas-Quesada, B.; de Moya-Anegón, F.; Glänzel, W. Improving SCImago Journal \& Country Rank (SJR) subject classification through reference analysis. Scientometrics 2011, 89, 741-758. [CrossRef]

109. Liu, L.; Mei, S. Visualizing the GVC research: A co-occurrence network based bibliometric analysis. Scientometrics 2016, 109, 953-977. [CrossRef]

110. Fellnhofer, K. Visualised bibliometric mapping on smart specialisation: A co-citation analysis. Int. J. Knowl. Based Dev. 2018, 9, 76. [CrossRef]

111. Zhou, S.; Tao, Z.; Zhu, Y.; Tao, L. Mapping theme trends and recognizing hot spots in postmenopausal osteoporosis research: A bibliometric analysis. PeerJ 2019, 7, e8145. [CrossRef]

112. Van Eck, N.J.; Waltman, L. Software survey: VOSviewer, a computer program for bibliometric mapping. Scientometrics 2009, 84, 523-538. [CrossRef] [PubMed]

113. Kartawijaya, R.; Hamsal, I.M. FINTECH: FinTech Entrepreneurs versus Banks in Indonesia. Adv. Sci. Lett. 2018, 24, 264-266. [CrossRef]

114. Nakashima, T. Creating credit by making use of mobility with FinTech and IoT. IATSS Res. 2018, 42, 61-66. [CrossRef]

115. Kurniawan, E.; Lubis, A.H.; Suherdi, D.; Danuwijaya, A.A. Rhetorical Organization of Applied Linguistics Abstracts: Does Scopus Journal Quartile Matter? GEMA Online ${ }^{\circledR}$. J. Lang. Stud. 2019, 19, 184-202. [CrossRef]

116. Nitayaprapha, S. FinTech Business Models: An Investigation of Thai Banks. Int. J. Sci. Res. Publ. (IJSRP) 2020, 10, 10042. [CrossRef] 
117. Qing, W. Research on the Inclusive Finance of rural Development Based on Internet Finance in China. Sci. Innov. 2016, 4, 267. [CrossRef]

118. Levitas, E.; Ann McFadyen, M. Multicomponent signals and financial constraints. Technol. Anal. Strateg. Manag. 2019, 32, 397-412. [CrossRef]

119. Guo, L.; Shi, F.; Tu, J. Textual analysis and machine leaning: Crack unstructured data in finance and accounting. J. Financ. Data Sci. 2016, 2, 153-170. [CrossRef]

120. Schueffel, P. Taming the Beast: A Scientific Definition of Fintech. J. Innov. Manag. 2017, 4, 32-54. [CrossRef]

121. Sloboda, L.Y.; Demianyk, O.M. Prospects and Risks of the Fintech Initiatives in a Global Banking Industry. Probl. Econ. 2020, 1, 275-282. [CrossRef]

122. Homocianu, D.; Sireteanu, A.; Dospinescu, O.; Airinei, D. An Analysis of Scientific Publications on “Decision Support Systems" and "Business Intelligence" Regarding Related Concepts Using Natural Language Processing Tools. In Proceedings of the 18th International Conference on Informatics in Economy Education, Research and Business Technologies, Bucharest, Romania, 30-31 May 2019; pp. 99-104. [CrossRef]

123. Chen, L. From Fintech to Finlife: The case of Fintech Development in China. China Econ. J. 2016, 9, $225-239$. [CrossRef]

124. Dash, R.; Dash, P.K. A hybrid stock trading framework integrating technical analysis with machine learning techniques. J. Financ. Data Sci. 2016, 2, 42-57. [CrossRef]

125. Liu, Q. How Good Is Good News? Technology Depth, Book-to-Market Ratio, and Innovative Events. J. Account. Audit. Financ. 2006, 21, 293-321. [CrossRef]

126. Zhuravleva, N.A. Digital economy as the basis of high-speed economy. Transp. Syst. Technol. 2017, 3, 47-49. [CrossRef]

127. Varma, A. Fintech Adoption Choices of Small Businesses: A Technology Organization Environment (TOE) Framework study. Account. Financ. Res. 2019, 8, 86. [CrossRef]

128. Kwon, S.S.; Yin, J. A comparison of earnings persistence in high-tech and non-high-tech firms. Rev. Quant. Financ. Account. 2013, 44, 645-668. [CrossRef]

129. Zouhair, A.; Kasraie, N. Disrupting Fintech: Key Factors for Adopting Bitcoin. Bus. Econ. Res. 2019, 9, 33. [CrossRef]

130. Siregar, B. Direct and indirect effects of investment on community welfare. Invest. Manag. Financ. Innov. 2019, 16, 206-216. [CrossRef]

131. Yeşil, S.; Doğan, I.F. Exploring the relationship between social capital, innovation capability and innovation. Innovation 2019, 21, 506-532. [CrossRef]

132. Collingro, F.; Frenkel, M. On the financial market impact of euro area monetary policy: A comparative study before and after the Global Financial Crisis. Glob. Financ. J. 2019, 100480. [CrossRef]

133. Carlson, M.; Rose, J. The incentives of large sophisticated creditors to run on a too big to fail financial institution. J. Financ. Stab. 2019, 41, 91-104. [CrossRef]

134. Wakaisuka-Isingoma, J. Corporate governance and performance of financial institution. Corp. Ownersh. Control 2019, 16, 203-216. [CrossRef]

135. Scheubel, B.; Stracca, L.; Tille, C. Taming the global financial cycle: What role for the global financial safety net? J. Int. Money Financ. 2019, 94, 160-182. [CrossRef]

136. Thatawong, P.O.; Jiamsanguanwong, A. User requirement and usability testing framework for information system development: Case study of financial institution. IOP Conf. Ser. Mater. Sci. Eng. 2020, 784, 012032. [CrossRef]

137. Ashta, A.; Biot-Paquerot, G. FinTech evolution: Strategic value management issues in a fast changing industry. Strateg. Chang. 2018, 27, 301-311. [CrossRef]

138. Hung, J.-L.; Luo, B. FinTech in Taiwan: A case study of a Bank's strategic planning for an investment in a FinTech company. Financ. Innov. 2016, 2, 1-16. [CrossRef]

139. Sung, A.; Leong, K.; Sironi, P.; O’Reilly, T.; McMillan, A. An exploratory study of the FinTech (Financial Technology) education and retraining in UK. J. Work-Appl. Manag. 2019, 11, 187-198. [CrossRef]

140. Harisa Putri, W.; Nurwiyanta, N.; Sungkono, S.; Wahyuningsih, T. The emerging fintech and financial slack on corporate financial performance. Invest. Manag. Financ. Innov. 2019, 16, 348-354. [CrossRef]

141. Vijai, C. Fintech in India-opportunities and challenges. Saarj J. Bank. Insur. Res. 2019, 8, 42. [CrossRef]

142. Wang, R.; Luo, H. Does Financial Liberalization Affect Bank Risk-Taking in China? SAGE Open 2019, 9, 215824401988794. [CrossRef] 
143. Kok, S.C.; Munir, Q. Malaysian finance sector weak-form efficiency: Heterogeneity, structural breaks, and cross-sectional dependence. J. Econ. Financ. Adm. Sci. 2015, 20, 105-117. [CrossRef]

144. Dos Santos, B.L.; Peffers, K.; Mauer, D.C. The Impact of Information Technology Investment Announcements on the Market Value of the Firm. Inf. Syst. Res. 1993, 4, 1-23. [CrossRef]

145. Guo, M. Financial System Analysis and Research of OLAP and Data Warehouse Technology. Inf. Technol. J. 2014, 13, 522-528. [CrossRef]

146. Petrošiene, B.; Urkiene, J.; Šidlauskiene, D. Financial statements formation in the context of the management paradigm. Humanit. Bull. Zaporizhzhe State Eng. Acad. 2019, 76, 210-220. [CrossRef]

147. Payment Services (PSD 2)-Directive (EU) 2015/2366. Available online: https://ec.europa.eu/info/law/paymentservices-psd-2-directive-eu-2015-2366_en (accessed on 12 May 2020).

148. Harms, R.; Schwery, M. Lean Startup: Operationalizing Lean Startup Capability and testing its performance implications. J. Small Bus. Manag. 2019, 58, 200-223. [CrossRef]

149. Deng, X.; Huang, Z.; Cheng, X. FinTech and Sustainable Development: Evidence from China based on P2P Data. Sustainability 2019, 11, 6434. [CrossRef]

(C) 2020 by the authors. Licensee MDPI, Basel, Switzerland. This article is an open access article distributed under the terms and conditions of the Creative Commons Attribution (CC BY) license (http://creativecommons.org/licenses/by/4.0/). 